\title{
Aggregált fiskális stabilizációs politika: csodaszer vagy búnbak?*
}

\author{
P. Kiss Gábor
}

A fiskális stabilizációhoz kapcsolódó elemzéseket számos esetben egyidejüleg jellemzik a tévedések és kihagyások. Tanulmányunk ezekkel foglalkozik. Az automatikus stabilizátorok és az EU-büdzsé stabilizáló hatása mellett azt vizsgáljuk, hogy a költségvetési hiány jelentős mértékü változásán alapuló stabilizációs politika lehet-e tartós és sikeres. Amíg a gazdasági növekedés ütemére a hiányt növelő impulzus hat, addig a gazdasági teljesítmény szintjére a deficit. A tartós hiány kumulálásából adódó adósság azonban gyorsabban nő, mint a GDP-re gyakorolt hatás, így az adósságráta belátható időn belül ugrásszerü növekedésbe kezdhet. Bemutatjuk, hogy egy folyamatos keresletbövítés kizárólag abban a valószínütlen esetben lehetne önfinanszírozó, ha a középtávú multiplikátor értéke 3-hoz közelítene, vagyis egy nominális lazítás reálértékben mért hatása permanens jelleggel háromszorosára nőne. A tartós, nagymértékü általános keresletbővités tehát nem csodaszer, az irodalom szerint azonban az alternativái, a strukturális reform és a célzott intézkedések alkalmasabb, kevésbé költséges eszközt jelentenek a GDP tartós növelésére. Hasonló eredményeket kaptak a célzott intézkedésekre vonatkozó magyar tapasztalatokat feldolgozó szimulációk is.

Journal of Economic Literature (JEL) kódok: E32, E61, E62, H62, H63

Kulcsszavak: fiskális politika, általános keresletbővítés, fiskális multiplikátor, gazdaságpolitikai koordináció

\section{Bevezetés}

A 2007-ben kezdődő gazdasági válság előtérbe helyezte a monetáris politika stabilizációs szerepét. A fiskális politika ezzel szemben számos országban - így az Európai Unióban - kevésbé volt aktív annak ellenére, hogy hagyományosan erős a gazdasági stabilizációs szerepe. Felmerül az a kérdés, hogy ez mennyiben járulhatott hozzá, hogy a gazdasági növekedés nem tért vissza a válságot megelőző trendjéhez (Lehmann et al. 2020).

\footnotetext{
* A jelen kiadványban megjelenő írások a szerzők nézeteit tartalmazzák, ami nem feltétlenül egyezik a Magyar Nemzeti Bank hivatalos álláspontjával.

P. Kiss Gábor a Magyar Nemzeti Bank föosztályvezetője. E-mail: kissg@mnb.hu

A szerző kiemelten köszönetet szeretne mondani Bögöthy Zoltánnak és Szőke Katalinnak segítségéért, továbbá Baksay Gergelynek, Morvay Endrének és a két anonim lektornak észrevételeikért. Minden fennmaradó hiba a szerző felelőssége.

A magyar nyelvű kézirat első változata 2020. március 17-én érkezett szerkesztőségünkbe.
}

DOI: http://doi.org/10.25201/HSZ.19.2.5587 
A fiskális politika definíciója magában foglalja a költségvetési egyenlegre, továbbá az adókra és kiadásokra vonatkozó politikák összességét (Cottarelli - Keen 2012, Tanzi - Zee 1997, IMF 2015). Az aktuálisan érvényes fiskális politika kapcsán felvetődik a kérdés, hogy fenntartható-e, hiszen a „folyamatos kormányzati finanszírozási igény folyamatosan növekvő államadóssághoz vezet" (Domar 1944). A fiskális politika hagyományos funkciói között van a ciklikusan ingadozó gazdasági aktivitás stabilizálása, a közjavak biztosítása (allokációja) és a jövedelmek újraelosztása (Musgrave 1959). E funkciók ellátása a gazdasági teljesítményre közvetlen (allokáció és stabilizáció) vagy közvetett (újraelosztás) hatással van. Bizonyos körülmények között feltételezhető, hogy ez a hatás a GDP mellett a potenciális növekedési ütemre is kiterjedhet. A fiskális stabilizációval kapcsolatban azonban számos félreértés van; a következő fejezetekben néhány időszerű kérdéssel foglalkozunk.

A második fejezetet annak bemutatásával kezdjük, hogy a növekedésre nem a deficit, hanem annak változása hat. Ezt követően ismertetjük az e változás hatására, multiplikátorára vonatkozó elképzeléseket. A harmadik fejezet azokra a véleményekre reagál, melyek figyelmen kívül hagyják a diszkrecionális intézkedés optimális jellemzőire vonatkozó konszenzust. ${ }^{1}$ Ennek szélsőséges formája az átmeneti jelleg elvetése, amiből tartós lazítás következhet. Egyszerű szimulációval bizonyítjuk, hogy ez nem lehetséges, és ennek akadályát nem a maastrichti kritériumok konkrét értékei jelentik.

A negyedik fejezet emlékeztetni kíván az irodalomban gyakran figyelmen kívül hagyott automatikus stabilizátorokra. Sem hatásukról, sem arról az elvről nem érdemes elfeledkezni, hogy „,hagyjuk az automatikus stabilizátorokat működni”. Az ötödik fejezet bemutatja, hogy a kibocsátási rés becslési bizonytalansága és utólagos revíziója gyakran gátolja az automatikus stabilizátorok zavartalan múködését, sőt a ciklus téves becslésén keresztül éppen prociklikus fiskális politikát eredményez. Példát mutatunk arra is, amikor a stabilizáció és a fenntarthatóság szempontja ellentétbe kerül.

A hatodik fejezet azon felvetések realitását kérdőjelezi meg, amelyek szerint képezhető lenne egy olyan nagyságú EU-büdzsé, ami a monetáris unió szintjén érzékelhető mértékű stabilizációt eredményezhetne. A hetedik fejezet vitatja azt a nézetet, hogy a monetáris politika mellett csak az általános fiskális keresletbővítés eszközével érdemes számolni. Egyrészt emlékeztetünk arra, hogy a fiskális politika célzottsága meghatározó, hiszen az egyes intézkedések rövid és hosszú távú kibocsátásra gyakorolt hatása nagyon eltérő. Bemutatjuk, hogy egyenlegsemleges - aggregált keresletet nem érintő - intézkedési csomag is elérhet pozitív hatást. ${ }^{2}$ Másrészt fel-

\footnotetext{
${ }^{1}$ A diszkrecionális intézkedésnek jól időzítettnek, átmenetinek és célzottnak kellene lenniük. Az irodalomban mostanában előfordul, hogy legfeljebb a jól időzített jelleg, vagyis a késlekedés elkerülésének fontosságát ismerik el, ami a prociklikusság elkerülése érdekében szükséges.

2 Matolcsy (2015), Palotai (2017), Baksay és Csomós (2014), Szoboszlai et al. (2018)
} 
hívjuk a figyelmet arra, hogy további gazdaságpolitikai eszközök kerültek előtérbe. A strukturális és versenyképességi reformok, valamint a makro- és mikroprudenciális eszközök a stabilizálás feladata mellett a potenciális növekedést is támogathatják.

\section{Fiskális impulzus és fiskális multiplikátorok}

A fiskális politika aggregált értelemben (eltekintve a bevételi-kiadási szerkezettől) akkor van érdemi hatással a gazdasági növekedésre, ha a deficit jelentősebben változik, és magas a multiplikátor értéke. A rövid távú multiplikátorok nagyságára különböző becslések vannak, a hosszú távú multiplikátoroknak azonban még az előjele is bizonytalan. A következőkben először annak bizonyításával foglalkozunk, hogy nem a deficit, hanem annak változása - a fiskális impulzus - van hatással a növekedésre. Ezután térünk át a multiplikátorokra vonatkozó becslések és elképzelések bemutatására, és annak illusztrálására, hogy mekkora különbséget okozhat, ha az egyiket vagy a másikat választjuk.

A fiskális politika rövid távú hatását az alábbiakban Chand (1993) levezetését követve mutatjuk be.

Zárt gazdaságban a következő azonosságok írhatók fel:

$$
\begin{gathered}
Y=C+I+G \\
T=t(Y),
\end{gathered}
$$

ahol $Y$ a gazdasági kibocsátás, $C$ a lakossági fogyasztás, I a privát beruházás, $G$ a kormányzati kiadás, $T$ a kormányzati adóbevétel és $t$ az effektív adóráta.

Most tegyük fel azt, hogy e változók közül / és $G$ exogén módon határozódik meg. A fogyasztás esetében azt feltételezzük, hogy az az adott évi jövedelemnek az arányos része:

$$
C=c(Y-T),
$$

ahol c a fogyasztási határhajlandóság.

$A z(1),(2)$ és (3) összefüggések alapján, bevezetve az $\alpha$ multiplikátort,

$$
Y=\frac{1}{1-c(1-t)}(I+G)=\alpha(I+G) .
$$


Chand (1993) levezetését követve (4) totális differenciálásával és előző periódusbeli számszerúsítéssel az alábbi eredményt kapjuk:

$$
\Delta Y=\alpha_{-1}(\Delta I+\Delta G)+\left(I_{-1}+G_{-1}\right)\left\{-\alpha_{-1}^{2} c_{-1} \Delta t+\left(1-t_{-1}\right) \alpha_{-1}^{2} \Delta c\right\},
$$

vagyis a GDP változása a két exogénnek feltételezett változó ( és G) bázisévi multiplikátorral szorzott változásától függ, továbbá a multiplikátor tárgyévi változásától, ami egyrészt függ az adóráta, másrészt a fogyasztási határhajlandóság változásaitól.

Az effektív adóráta változásának adóbevételre gyakorolt hatása:

$$
\Delta t Y_{-1}=\Delta T-t_{-1} \Delta Y .
$$

A fogyasztási határhajlandóság változásának fogyasztásra gyakorolt hatása:

$$
\Delta c Y_{-1}=\frac{\Delta C}{1-t_{-1}}-c_{-1} \Delta Y \text {. }
$$

Felhasználva, hogy $Y=\alpha(I+G)$, a GDP változását leíró (5) egyenlet átírható:

$$
\Delta Y=\alpha_{-1}(\Delta I+\Delta G)+Y_{-1}\left\{-\alpha_{-1} c_{-1} \Delta t+\left(1-t_{-1}\right) \alpha_{-1} \Delta c\right\} .
$$

Az effektív adóráta (6) és fogyasztási határhajlandóság (7) változásának hatását leíró egyenleteket behelyettesítve, és $Y_{-1}$-vel végigosztva

$$
\frac{\Delta Y}{Y_{-1}}=\alpha_{-1}\left\{\left(\frac{\Delta I}{I_{-1}} \frac{I_{-1}}{Y_{-1}}+\frac{\Delta G}{G_{-1}} \frac{G_{-1}}{Y_{-1}}\right)-c t_{-1}\left(\frac{\Delta T}{T_{-1}}-\frac{\Delta Y}{Y_{-1}}\right)+c_{-1}\left(\frac{\Delta C}{C_{-1}}-\frac{\Delta Y}{Y_{-1}}\right)\right\} .
$$

Amennyiben a fenti, tényleges növekedést felbontó egyenletből levonjuk az egyensúlyi növekedésre $(n)$ felírt semleges pályát, az alábbi egyenlet adódik:

$$
\begin{array}{r}
\frac{\Delta Y}{Y_{-1}}-n=\alpha_{-1}\left\{\left(\frac{\Delta I}{I_{-1}}-n\right) \frac{I_{-1}}{Y_{-1}}+\left[\left(\frac{\Delta G}{G_{-1}}-n\right) \frac{G_{-1}}{Y_{-1}}\right.\right. \\
\left.\left.-c t_{-1}\left(\frac{\Delta T}{T_{-1}}-\frac{\Delta Y}{Y_{-1}}\right)\right]+c_{-1}\left(\frac{\Delta C}{C_{-1}}-\frac{\Delta Y}{Y_{-1}}\right)\right\} .
\end{array}
$$

Kérdés azonban, hogy a kiadások növelése esetében mi tekinthető intézkedésnek. Chand (1993) levezetését követve megállapítható, hogy abban az esetben, ha a fogyasztási határhajlandóság $(c)$ és az effektív adóráta $(t)$ nem változik, akkor az aktuális gazdasági növekedés csak akkor térhet el a trendtől $(n)$, ha a beruházások vagy a kormányzati kiadások növekedése eltér ugyanattól a növekedési trendértéktől $(n)$ :

$$
\frac{\Delta Y}{Y_{-1}}=\alpha_{-1}\left(\frac{\Delta I}{I_{-1}} \frac{I_{-1}}{Y_{-1}}+\frac{\Delta G}{G_{-1}} \frac{G_{-1}}{Y_{-1}}\right)
$$


A kormányzati kiadás növekedési ütemének eltérése az $\mathrm{n}$ értéktől intézkedést jelent, az adóknak a gazdasági növekedéstől való eltérése - ha eltekintünk a progresszív adórendszertől - szintén intézkedésre, az effektív adóráta változására utal. A képletből egyértelmúen megállapítható, hogy a rövid távú GDP-re nem a fiskális egyenleg, hanem annak változása van hatással. Ennek következménye az, hogy a rövid távú gazdasági növekedés ütemének folyamatosan magas szinten tartásához a fiskális egyenleg folyamatos romlására lenne szükség. A huzamos ideig növekvő hiány azonban egy ponton finanszírozhatatlan államadósságot és hiteltelen fiskális politikát eredményezhet.

A (10) képletben a költségvetési tételek szögletes zárójelben levő része a fogyasztási határhajlandóság kivételével megegyezik az ún. „holland” fiskális impulzussal (Chand 1977):

$$
\frac{F I}{Y_{-1}}=\left(\frac{\Delta G}{G_{-1}}-n\right) \frac{G_{-1}}{Y_{-1}}-\left(\frac{\Delta T}{T_{-1}}-\frac{\Delta Y}{Y_{-1}}\right) \frac{T_{-1}}{Y_{-1}} .
$$

Ez a „holland” fiskális impulzus mutató a diszkrecionális intézkedések hatását úgy határozza meg, hogy a gazdasági ciklus változásának költségvetési hatását kiszűri, tehát úgy is felfogható, mint a tárgyévi és bázisévi ciklikusan igazított költségvetési egyenlegek különbsége. Ez a mutató elvben a diszkrecionális intézkedések elsőkörös hatására vonatkozik, azonban az adóbevételt nem korrigálja a fogyasztási határhajlandósággal. Most oldjuk fel azt a feltételezést, hogy a beruházás exogén változó és a gazdaság zárt. Ilyen módon a diszkrecionális intézkedések a beruházási multiplikátoron keresztül is hatnak, a nyitottság bevezetésével pedig az import ( $M$ ) és export $(X)$ is megjelenthet, ami szintén érinti a fiskális politika hatását. A fogyasztási multiplikátorra vonatkozóan ez azt jelenti, hogy annak nagysága a fogyasztáshoz tartozó import-határhajlandóság $\left(m_{C}\right)$ mértékének figyelembevételével csökken:

$$
\alpha=\frac{1}{1-c(1-t)+m_{C}} .
$$

A fiskális politika hatását illetően a közgazdasági elmélet különböző válaszokat ad, és a sokféleség az empirikus vizsgálatok eredményeiben is megmutatkozik. A következőkben először röviden az elméleti, majd az empirikus megközelítéssel foglalkozunk.

A modern elméletek többsége elfogadja, hogy a rövid távú fiskális hatást az újkeynesiánus mechanizmusok határozzák meg, abból adódóan, hogy a verseny és az ár- és bérrugalmasság nem tökéletes. Mindez a gazdasági ciklus egyes pontjain keynesi kereslethiányhoz vezethet, vagyis egy fiskális lazítás a ragadós árak és bérek miatt növeli a háztartások rendelkezésre álló jövedelmét, a magánfogyasztást és a GDP-t. Ezt a közvetlen keynesi hatást erősíti például a tőkepiacok tökéletlensége és a likviditáskorlátos fogyasztók nagy aránya, de gyengíthetik vagy ellentételezhetik más, nem-keynesi hatások. 
Ilyen gyengítő hatást eredményezhet az, ha a piacok mégis hatékonyabban múködnek, valamint a gazdasági nyitottság [(13) képlet], a munkapiaci és versenyképességi kompenzációs hatás és a kamat- és árfolyam-reakciók. A kamat egyrészt a beruházások kamatérzékenységén ${ }^{3}$, másrészt a vagyonhatáson keresztül hat, végül a kamatprémium változtatásával a nettó exportra gyakorolt hatáson keresztül is hatással lehet. ${ }^{4}$ Gyengítő hatása van a háztartások heterogenitásának is, ugyanis ezek az eltérő jövedelmi/vagyoni csoportok különböző hitelezési (Hayashi 1987) vagy megtakarítási (Mankiw 2000) ellensúlyozó mechanizmusok fokozatos kibontakozásán keresztül ellentételezhetik az intézkedés hatását.

Ellentételező hatás - és akár negatív multiplikátor is - következhet az újklasszikus iskola (Bernheim 1989) azon feltételezéséből, hogy a fiskális lazítás erős kiszorítási hatása miatt a privát fogyasztás és beruházás csökken, miközben a munkakínálat GDP-re gyakorolt pozitív hatása nem jelentős. Ezen érvelés szerint a tőkepiaci egyensúly azt igényli, hogy a lakosság a lazítás idején államkötvényt vásároljon, és a megtakarítások simítása érdekében visszafogja a privát beruházást (Strulik - Trimborn 2013). Ez a tőkeállomány leépüléséhez vezethet, és a termelés csökkenését vonja maga után, ami csak hosszú távon áll helyre.

A modern elméletek eltérnek annak megítélésében, hogy közép- és hosszú távon mekkora a fiskális multiplikátor. Az újklasszikus és keynesi elmélet szintézise szerint rövid távon az újkeynesiánus mechanizmusok hatnak, de hosszú távon az újklaszszikus összefüggések érvényesülnek. A középtávon még alacsonyabb tőkeállomány (negatív középtávú multiplikátor) hosszú távon visszatér az egyensúlyhoz (nulla hoszszú távú multiplikátor).

A hagyományos újkeynesi megközelítésben közép- és hosszú távon nullára csökken a multiplikátor, a gazdaság visszatér a munkanélküliség természetes rátája melletti egyensúlyhoz. A válságot követően azonban egyre többen állítják azt, hogy a multiplikátor pozitív maradhat. Érvelésük szerint a potenciális kibocsátás endogén, nem független az aggregált kereslet pályájától. Elhúzódó recesszió idején ugyanis a magas ciklikus munkanélküliség átalakulhat strukturálissá, a munkaerő tudása leértékelődik és kiszorul a munkapiacról, így pedig csökken a potenciális GDP (DeLong - Summers 2012). Az a fiskális lazítás tehát, ami ezt megakadályozza, ceteris paribus növeli a potenciális kibocsátást, vagyis hosszabb távon is pozitív multiplikátort eredményezhet.

\footnotetext{
${ }^{3} \mathrm{~A}$ beruházásoknak három tényezője különböztethető meg. Az autonóm beruházás esetében a beruházási határhajlandóság nulla, ide tartozhatnak az állami beruházások. A beruházások másik két komponense a jövedelemtől, illetve a kamattól függ. A kamatok bekapcsolása kimutatja azt a csatornát, hogy a beruházások érzékenyek a tőkeköltségek változására.

${ }^{4}$ Ez a csatorna a gyenge keynesi vagy nem-keynesi megközelítésben fejtheti ki a hatását. Egyik magyarázata az, hogy a fiskális lazítás/szigorítás hitelességi hatása növelheti/csökkentheti a kamatprémiumot. Ez fel/ leértékelheti az árfolyamot, és csökkentheti/növelheti a nettó exportot, természetesen attól is függően, hogy reagál-e a monetáris politika. Másik magyarázata az, hogy a magasabb/alacsonyabb kamatprémium visszafoghatja/élénkítheti a múködőtőke-beáramlást, ami ronthatja/javíthatja a vállalatok exportversenyképességét.
} 
A modern elméletek eltérő rövid és középtávú fiskális multiplikátorait foglalja össze a sematikus 1. ábra, egy fiskális lazítás hatásának lehetséges lefutásait ábrázolva az idő függvényében. Ez felhívja a figyelmet arra, hogy a rövid távú multiplikátor minden elméleti keretben nagymértékben eltér a középtávútól, és a fiskális élénkítés értékelése során ezt nem szabadna figyelmen kívül hagyni (Guest - Makin 2011). A felső szaggatott vonal a hiszterézis jelenségével összefüggő hatást mutatja, itt a keresletbővítő fiskális politikának hosszú távon is pozitív hatása lehet a magasabb potenciális GDP-n keresztül. A következő szaggatott vonal a gyengén keynesi hatást mutatja, ahol szintén pozitív a kapcsolat a lazítás és a GDP között, de hosszabb távon ez nulla. A középső, vastag vonal az újklasszikus és keynesi elmélet szintézisének megfelelő válasz függvényre ad példát, ahol középtávon a keynesi hatásokat meghaladják az ellentétes irányú csatornák, hosszú távon pedig ez is nullához tart. Az alsó pontozott vonal az újklasszikus fiskális hatás reakció-függvényét ábrázolja. Itt már rövidebb távon is túlsúlyba kerülnek a nem-keynesi csatornák, és ezzel a teljes hatás hamarabb negatívvá válik, majd hosszú távon szintén nulla lesz. Ez az ábra nemcsak azt illusztrálja, hogy a rövid és középtávú fiskális multiplikátor eltérő, hanem azt is, hogy a rövid távú multiplikátort sem szabad az első éves multiplikátorral azonosítani. $^{5}$

\section{1. ábra \\ Fiskális multiplikátorok ugyanolyan mértékű impulzus esetén}

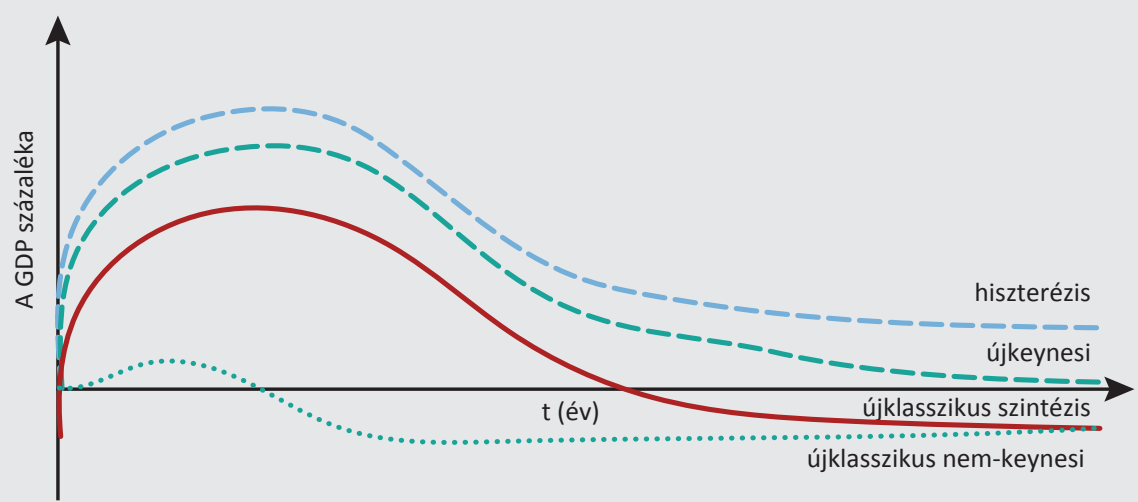

Megjegyzés: A GDP-tengely skálázása szándékosan hiányzik, az ábra célja egy séma bemutatása az egymáshoz viszonyított görbék segítségével. A konkrét értékek sok tényezőtöl függnek (pl. adó vagy kiadás stb.), rövid távon pedig nagyon ciklusfüggö.

Forrás: Horváth et al. (2006) és Strulik - Trimborn (2013) alapján szerkesztve.

Ahogyan az elmélet különféle rövid, közép- és hosszú távú multiplikátort feltételez, úgy az empirikus eredmények is többfélék. Ezen modellalapú és ökonometriai becslések közös jellemzője, hogy szerintük még a permanens fiskális intézkedések

\footnotetext{
${ }^{5}$ Hasonló ábrákat lásd: Strulik - Trimborn (2013), 2. ábra; Horváth et al. (2006), 1. ábra.
} 
hatása is eltűnik öt éven belül (Batini et al. 2014). Ez a folyamat nem lineáris, hanem fordított $U$ alakot mutat, ahol a második évben jelentkezik a maximum (Coenen et al. 2012). Ha egy általános keresletbővítés minden tételnél arányosan történik meg, akkor a kiadások csaknem fele közvetlenül megjelenik a nominális GDP szintjében, ennek azonban csak kisebb része a volumenben ( $p l$. beruházás, de 20-25 évre szétterítve), nagyobb része a deflátorban (pl. állami béremelés). Ráadásul az állami kiadások közvetlen adótartalma miatt az impulzusnak körülbelül egyötöde azonnal vissza is érkezik adóbevételként, így a nettó impulzus ennyivel kisebb. A fenti tényezők megmagyarázzák, hogy alapesetben egy bruttó impulzussal azonosított általános keresletbővítés multiplikátora miért mérsékelt.

A hatás nagysága és lefutása szempontjából egyrészt kiemelt fontosságú, hogy a fiskális sokk átmeneti vagy permanens, illetve milyen szerkezetben valósul meg. Az expanzív (nem-keynesi) fiskális konszolidáció irodalma kitüntetett szerepet tulajdonított a kiigazítás összetételének (például: Perotti 1996). A szerkezet fontosságáról az utolsó fejezetben lesz szó. Az adósságállomány nagysága is fontos, mert a multiplikátor akkor nagyobb, ha az adósságráta alacsonyabb (Huidrom et al. 2016). Magasabb adósságráta esetén a hiánynövelő intézkedések következtében bekövetkező hozamemelkedés a teljes gazdaságot érintheti, és így kiszoríthatják a magánberuházást és fogyasztást (Bi et al. 2014).

Másrészt meghatározó jelentőségű a gazdaság ciklikus pozíciója, a monetáris politika reakciója és a gazdaságpolitika többi eleme is. Több kutatás szerint a multiplikátor állapotfüggő, vagyis a ciklus során változik, aszimmetrikusan alakulhat, és nemlineáris jellemzői vannak (Auerbach - Gorodnichenko 2012a és 2012b). Az elhúzódó recesszió során a fiskális sokknak tartós hatása lehet a hiszterézis következtében ${ }^{6}$ (DeLong - Summers 2012). A monetáris politika szintén hozzájárulhat a fiskális politika hosszabb hatásához, amennyiben nem ellensúlyozza a fiskális lazítást kamatemeléssel. Ezáltal egy kétéves átmeneti lazítás hatását is öt évre terjesztheti ki a DSGE-modellek szerint (Coenen et al. 2012). A fiskális politika gyakran egy széleskörű makrogazdasági program részét képezi, és attól nehezen választható el. Ez történt az „expanzív fiskális konszolidáció” két legtöbbet hivatkozott esetében, Dániában és Írországban. ${ }^{7}$

A fiskális multiplikátorra vonatkozóan az empirikus irodalomban szereplő eltérések lehetséges okai egyrészt tartalmi, másrészt módszertani jellegűek. Tartalmi különbséget okoz, hogy az eredmények országonként mások. Ez nem meglepő, hiszen

\footnotetext{
${ }^{6}$ Amíg a nem tartós recesszió körülményei között a fiskális multiplikátor nullához közelít, addig tartós recesszió esetén a hosszabb távú multiplikátor még meg is haladhatja a rövid távút (DeLong - Summers 2012).

${ }^{7}$ Mindkét országban jelentős árfolyam-leértékelés volt, a kamatok és az infláció csökkent, liberalizálták a tőkeáramlást és a visszafogott bérdinamika is csökkentette az export árát. Írországban a munkapiac strukturális reformjára is sor került, és az EU- és EMS-tagság is kedvező hatást gyakorolt. Ezen az alapon többen (Eichengreen 1998, Prammer 2004, Barry 1991, Bradley - Whelan 1997) kétségbe vonják, hogy a dán és ír fiskális kiigazítások nem-keynesi jellegúek voltak.
} 
jelentős különbségek vannak minden fontos dimenzióban, például gazdasági fejlettségben, nyitottságban, eladósodottságban, monetáris politikai és árfolyamrendszerben, nominális és reálmerevségekben. Jelentős eltérést találtak a fejlett és kevésbé fejlett országok között az OECD és a Világbank adatbázisai alapján Giavazzi és szerzőtársai (2000). A fejlett országokon belül is előjelében eltérő eredmények adódtak az Egyesült Államok és az Egyesült Királyság között (Jones et al. 2015), ami az USA egyedülálló jellemzőivel függhet össze. Ezek alapján egységes fiskális recept még az aggregált fiskális stabilizáció esetében sem képzelhető el (nemhogy a fiskális intézkedések szerkezetére vonatkozóan, amiről az utolsó fejezetben szólunk részletesebben).

Módszertani problémát jelent, hogy a becslés során milyen módon vehető figyelembe a fiskális politika és a többi változó közötti kapcsolat. A DSGE-modell alapján végzett szimulációk (Coenen et al. 2012) során a változók között részletes - mikrogazdasági döntéseket is tartalmazó - összefüggések érvényesülnek, azonban nem tudják kezelni a multiplikátorok állapotfüggő (aszimmetrikus és nemlineáris) jellemzőit. Az empirikus becslések (regresszió, VAR, SVAR) általában szintén lineárisak, így az állapotfüggő jelleget csak speciális esetben tudják megragadni (Auerbach - Gorodnichenko 2012a és 2012b). További módszertani probléma, amire később még visszatérünk, hogy a diszkrecionális intézkedéseket gyakran a ciklikusan igazított (elsődleges) deficit változásával azonosítják, ami torzításhoz vezet, hiszen a pénzügyi ciklusok hatását nem szürik ki. Az exogén fiskális sokkok megfelelő meghatározása más okokból sem valósul meg ebben a keretben. Romer és Romer (2010) például négyféle okot különböztet meg az adóintézkedések esetében. Ebből az első kettő endogén (a kibocsátást érintő egyéb hatásokkal összefügg), nevezetesen a kiadásokat, illetve a közeli jövőben a kibocsátást érintő egyéb hatásokat ellentételező intézkedések. Ezzel szemben exogén intézkedésnek tekinthetők a felhalmozódott adósság leépítése és a hosszú távú célok elérése érdekében hozott lépések. Az utóbbiak meghatározása érdekében jött létre az egyedi adóintézkedések közvetlen becslésére épülő narratív módszer. Ez egy másik módszertani problémára is felhívja a figyelmet, ugyanis figyelembe kell venni az intézkedések szerkezetét, vagyis hogy milyen adók és milyen kiadások változnak. Baksa és szerzőtársai (2014) a „Létezik „a" költségvetési multiplikátor?” című tanulmányukban megállapítják, hogy nem létezik egységes fiskális multiplikátor, és a fiskális expanzió különböző formái (a vizsgált formák: áfa, szja, szociális járulékok, pénzügyi transzferek, kormánykiadások) különböző multiplikátorokkal rendelkeznek. A modellalapú megközelítések általában megegyeznek abban, hogy az indirekt adók, transzferek és kormányzati fogyasztás permanens változása csak rövid távú hatást gyakorol a kibocsátásra, és ez öt éven belül el is túnik (Coenen et al. 2012). Ezzel szemben az állami beruházások vagy társasági adók tartós változtatásának akár tartós hatása lehet, és öt éven túlmenően is fennállhat, mert a gazdaság tőkeállományára hat (Coenen et al. 2012). Ha általános keresletbővitésről beszélünk, akkor ezeknek a tartósabb tételeknek a súlya sokkal alacsonyabb, mint a rövid távon ható tételeké, ezért azoknak a hatása lesz a meghatározó. 


\section{Egy kellemetlen aritmetika illusztrációja}

A következőkben egy egyszerú illusztrációt készítünk a multiplikátorok jelentőségéről. A 2. ábrán látható, hogy az államadósság 1995-ben és 2007-ben nagyon hasonló volt az euroövezetben és az USA-ban, ezt követően folyamatosan nő a különbség közöttük, hasonlóan a GDP esetében. Az illusztráció során megvizsgáljuk, hogy mekkora lenne az euroövezet adóssága abban a szcenárióban, amikor egy általános keresletbővítő fiskális politika folyamatosan 3 százalékos növekedést biztosítana 1995 és 2019 között. 3 százalékos növekedés esetén a 1995 és 2007 évi szétnyílás megszúnne az USA és az euroövezet között, 2008 után pedig nem csupán a növekedési ütem nem nyílna szét, de még az USA-ban jelentkező egyszeri szintbeli csökkenés sem jelentkezne. E rögzített növekedési ráta elérése annál nagyobb deficit- és adósságnövekedést követel meg, minél kisebb a multiplikátor, és megfordítva, a nagyobb multiplikátor kevésbé meredek hiánypályát igényel. Hogy kiderüljön, hogy a folyamatos aggregált lazítás csodaszer vagy csupán a búnbak szerepét tölti be, a multiplikátor lehetséges és lehetetlen értékeire egyaránt készítettünk szimulációkat.

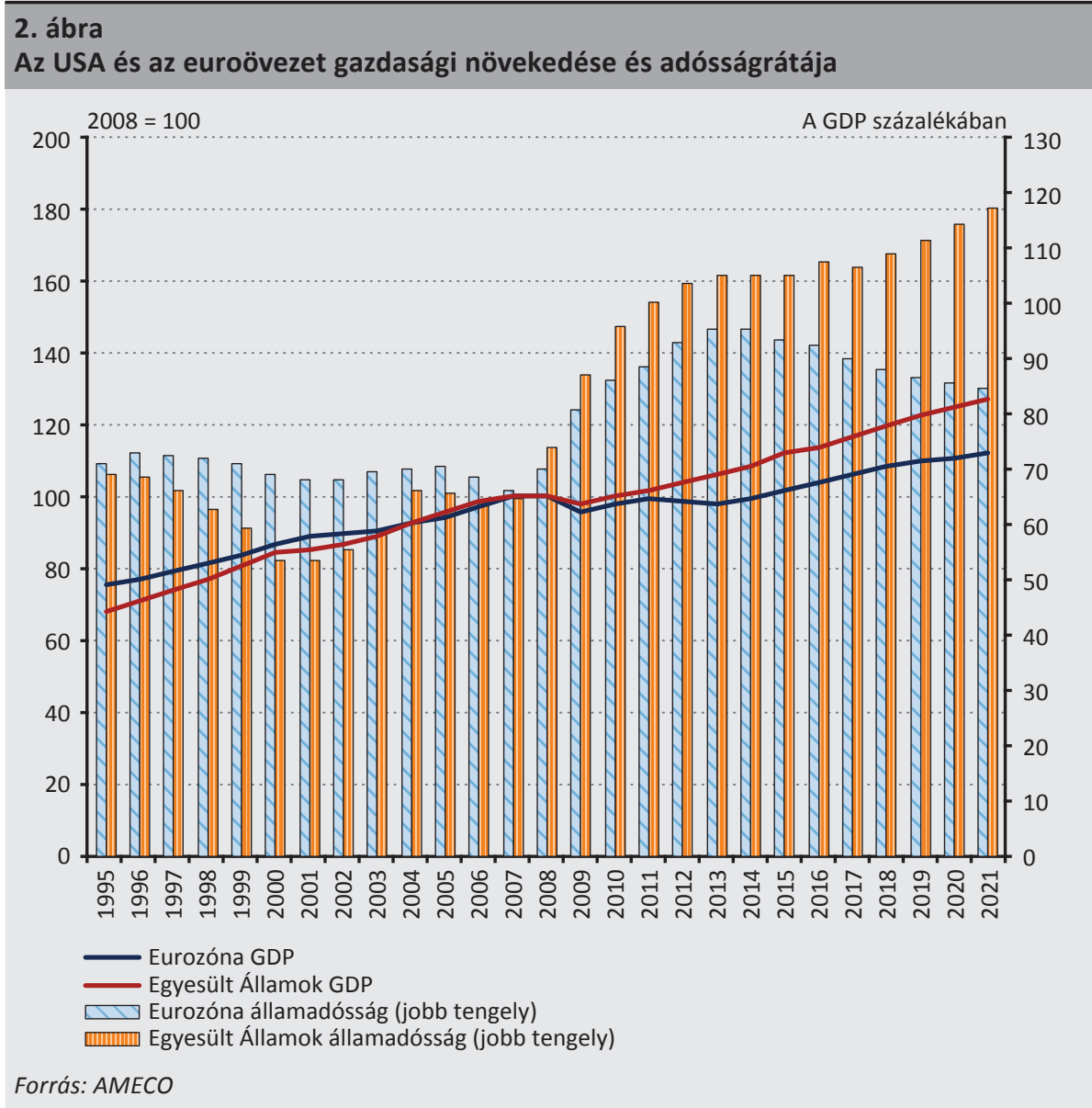


A szimuláció során különféle feltételezésekkel éltünk, ha döntési lehetőség volt, akkor az optimistább, kisebb adósságrátát eredményező változatot fogadtuk el. Kivétel ez alól a multiplikátorok megválasztása, hiszen itt célunk éppen az eltérő szcenáriók bemutatása. Az alapszcenárió egy újkeynesi hatásra épült, aminek öt évig a következő multiplikátorai vannak: 0,$5 ; 0,7 ; 0,5 ; 0,3 ; 0,1$; utána végig nulla. Számoltunk egy újklasszikus szintézisnek megfelelő változatot is, ami az előzőnél 0,1-gyel alacsonyabb multiplikátort feltételez az egész időhorizonton, így érzékenységvizsgálatnak is felfogható. A multiplikátor nulla közeli középtávú értékének az intuitív háttere a következő: Adott a GDP 1 százalékának megfelelő nominális keresletbővítés. Ebből 37 százalék visszatérül a költségvetésbe (ez volt az euroövezet adócentralizációs értéke 2008-ban). A nettó impulzus tehát 0,63, aminek mondjuk a fele a deflátorokban (kormányzati fogyasztás deflátora, $\mathrm{CPI}$ ) jelenik meg, a másik fele a reálváltozókban. Nyitott gazdaság esetén a reálhatás fele növeli a reál-GDP előállítását, vagyis nagyjából 0,16. Különböző ellensúlyozó mechanizmusok következtében ez középtávon nullához közeli érték lehet.

E két pálya mellett 2009 és 2018 között feltételeztünk egy hiszterézis-szcenáriót is, ahol a multiplikátor az egész időhorizonton 0,63-dal magasabb. Annak érdekében, hogy a lehetséges maximális növekedési és legkisebb adósságráta-hatást bemutassuk, erre a teljes időszakra azt feltételeztük, hogy a hiszterézishez szükséges feltételek teljesülhettek. Mivel az adótartalommal csökkentett, nettó impulzus 0,63, ezért ez a multiplikátorérték olyan, középtávon érvényesülő szélsőértéknek minősíthető, ahol az impulzus 100 százalékban hat, más szóval a nyitottságon, semlegesítő csatornákon és deflátoron keresztüli jelentős mértékủ elszivárgást teljes mértékben és hosszú időn keresztül ellensúlyozzák a tőkeállományt vagy a munkanélküliséget érintő pozitiv hatások (utóbbi korlátaitól is eltekintettünk). Ez optimista feltételezés, ha figyelembe vesszük, hogy nem célzott intézkedésről, hanem általános keresletbővítésről beszélünk, amikor olyan szereplők is részesülnek az impulzusból, akiknek nincsen rá szüksége, így aktivitásukat nem érinti. Érzékenységvizsgálat céljából készítettünk egy ennél is sokkal optimistább, extrémnek nevezhető szcenáriót, ahol a multiplikátor 2009-től 1,7-del magasabb, mint az alappálya volt.

Létezik egy középtávú multiplikátor, ahol önfinanszírozó a lazítás, ezt pedig a (13) képlet alapján az adócentralizációból lehet meghatározni. Ha az egyéb változók (nyitottság, fogyasztási határhajlandóság) hatását ellensúlyozhatják is más tényezők, a deficit szempontjából az számít, hogy mennyi adóbevétel térül vissza. Ez az érték a 37 százalékos adócentralizáció esetén 2,7, ami kívül áll a reálisan számításba vehető multiplikátorok körén. Ebben az esetben a nominális adósság nem változik, de a magasabb GDP miatt az adósságráta csökken. Ennek hatását is figyelembe véve - változatlan adósságrátát elérve - az önfinanszírozó középtávú multiplikátor 2,55.

Amennyiben egy 1 százalékos impulzus nem eredményez középtávon majdnem háromszor akkora GDP-szintet, akkor az adóból nem térül annyi vissza, hogy önfinanszírozó legyen. Ebben az esetben az egyes évek impulzusai deficitekké kumulálódnak, 
a deficitek pedig adóssággá. A deficit eredményeképpen magasabb a GDP, ez azonban a deficitek kumulálásából adódó adósságráta növekedését csak mérsékelni képes. Az eredmény, mint az ábrán látható, exponenciálisan növekvő adósság.

Az illusztratív számítás során a tényleges hiány- és adósságpályához hozzáadtuk azt a növekvő deficitet, amely a 3 százalékos folyamatos növekedés fenntartásához szükséges, ${ }^{8}$ azaz a felhalmozódó adósság kamatát a tényleges kamatfizetés és tényleges adósság alapján számított implicit kamatrátával. Egy adósságszinten túl irreális, mégis azt feltételezzük, hogy a magasabb adósság miatt a kamatprémium nem emelkedik, ami azt jelenti, hogy számításunk abszolút mértékben alsó becslésnek tekinthető a hiányt és adósságot illetően. Az így kapott nominális adósságot a tényleges és a 3 százalékos növekedéssel kapott GDP különbözetével korrigáljuk, hiszen a magasabb GDP ceteris paribus csökkenti az adósságrátát.

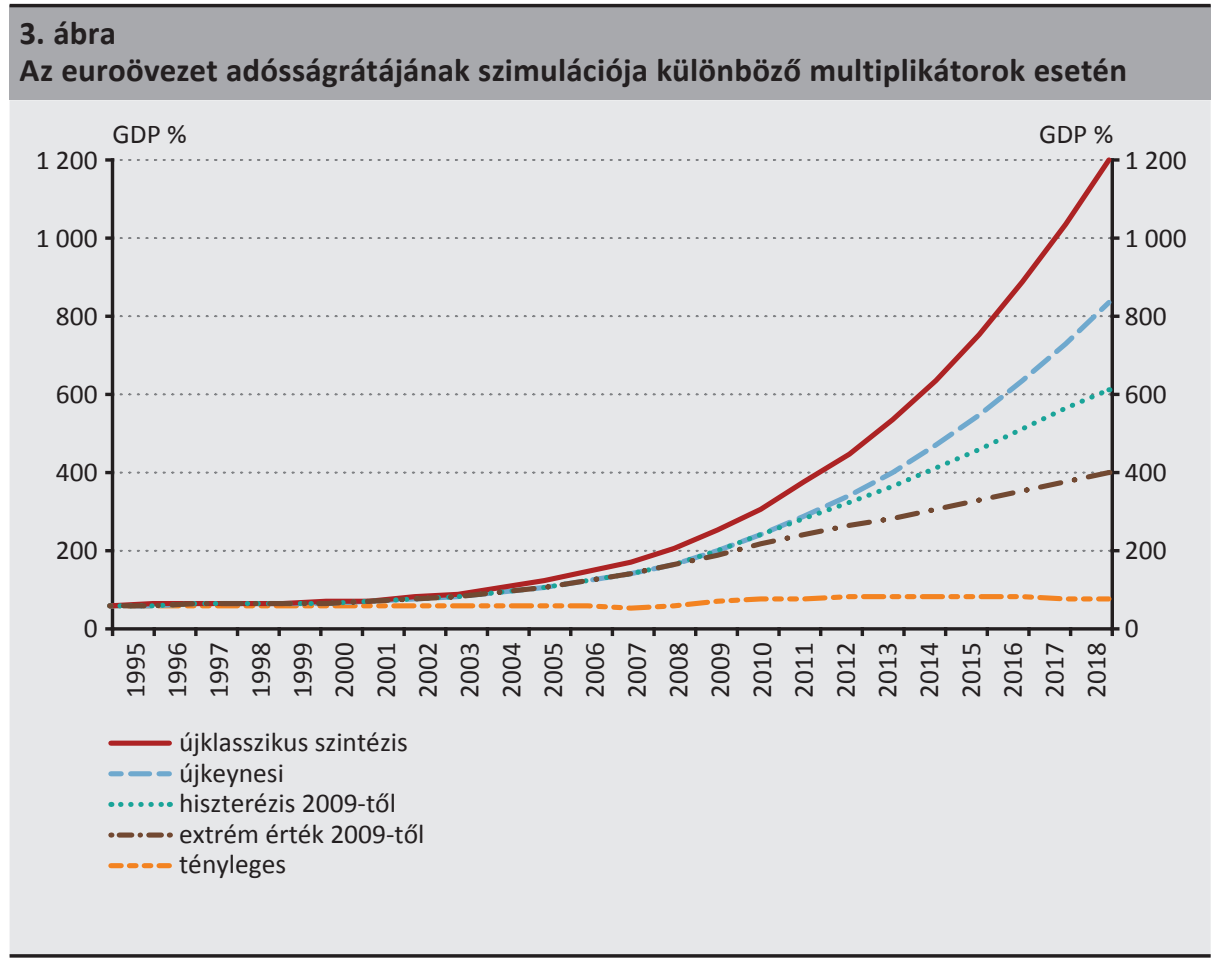

${ }^{8}$ A szükséges impulzus mértéke:

$$
\text { kiadás }_{t}=\left\{1,03 g d p_{t-1}-\left(1+\sum_{i=1996}^{t} \text { kiadás }_{i} \text { multiplikátor }_{t-i}\right)\right\} \frac{g d p_{t-1}}{\text { multiplikátor }_{0}},
$$

ahol multiplikátor ${ }_{0}$ az intézkedés azonnali hatását jelenti. Ennek eredményeképpen az adósságráta aránya t évben az 1995-ös rátához képest:

$$
\text { adósságráta } a_{t}=\frac{1+\sum_{i=1996}^{t}(1-\text { adócentralizáció }) \text { kiadás }_{i}}{\sum_{i=1996}^{t}\left(1+\text { kiadás }_{i} \text { multiplikátor }_{t-i}\right)} \text {. }
$$


Az eredmények szerint az adósságráta 1995 és 2008 között a tényleges pályához képest a gyenge újkeynesi hatás mellett a GDP 107 százalékával nőtt volna (amiből 9 százalékpont a kamat), az újklasszikus szintézis esetében pedig 148 százalékkal (kamat: 14 százalékponttal). A hiszterézis-szcenárióban az adósságráta változása 2008 és 2018 között több mint 442 százalékpont (kamat ebből 72 százalékpont) és az extrém értékek mellett is meghaladja a 228 százalékpontos növekményt (ebből 49 százalékpont a kamat). Ez azt mutatja, hogy a lazítás költségei idővel viszonylag hamar meghaladják az így keletkező hasznot, más szóval a tartós keresletélénkítés nem tekinthető csodaszernek. Megalapozott tehát a diszkrecionális intézkedés optimális jellemzőire vonatkozó konszenzus, ami az átmeneti jelleget hangsúlyozza.

Az illusztratív számítás alapján megállapítható, hogy a huzamos ideig tartó, számottevő mértékú és általános keresletbővítést a középtávon is jelentős költségek akkor is korlátoznák, ha az időnként túl szigorúnak ítélt maastrichti hiány- és adósságszabályok nem léteznének. Meg kell jegyezni, hogy az EU fiskális keretrendszere e két korlátnál sokkal összetettebb, így nehezebben ítélhető meg, hogy megfelelő stabilizációs és fenntarthatósági célokat tűz-e ki, azok elérése érdekében adekvát paramétereket alkalmaz-e, és adott esetben hogyan kezeli a célok között jelentkező átváltást. A keretrendszer folyamatos változása során egyrészt a fenntarthatósági szempont erősödésével párhuzamosan felértékelődött az eredetileg másodlagos jelentőségú állományi mutató (adósság) szerepe, másrészt a stabilizációs funkció érvényesülése a strukturális egyenlegcél (MTO) hangsúlyosabbá tevését igényelte. Az egyes tagállamok számára meghatározott MTO szokásos (nem kiugró) mértékú ciklikus ingadozás esetén elegendő biztonsági sávot (safety margin) biztosít ahhoz, hogy a hiány ne lépje túl a maastrichti 3 százalékos határértéket. ${ }^{9}$ Amíg korábban a maastrichti deficitráta és adósságráta határértékének konzisztenciáját vizsgálták, ma az MTO mint a gyakorlatban érvényesülő, nulla közelében levő cél és az adósság határértéke vethető össze. Ez alapján a jelenleg érvényesülő, trendjében alacsonyabb nominális GDP-növekedés is elegendő ahhoz, hogy a határértéken stabilizálja az adósságrátát (vö. Lehmann et al. 2020: 3. ábra).

\section{Automatikus stabilizátorok és diszkrecionális fiskális intézkedések}

Az automatikus stabilizátorok hatásának érvényesülése nem látványos, ezzel kapcsolatban azt az elvet fogalmazták meg, hogy „,hagyjuk az automatikus stabilizátorokat múködni." Ez más szóval azt jelenti, hogy ne hozzunk ellentétes irányú intézkedéseket. A fiskális politika döntéshozói értelemszerűen éppen ez utóbbi, konkrét diszkrecionális intézkedésekre koncentrálnak. A konkrét lépésekre összpontosító narratív módszer kivételével azonban a többi elemzés és kutatás a diszkrecionális

\footnotetext{
${ }^{9}$ A tagállam számára ezenfelül mentesítő feltételt jelent, ha rendkívüli esemény vagy tartós és jelentős gazdasági visszaesés következik be. Ezt negatív növekedési ütemként, illetve a kibocsátásnak a potenciális növekedéstől való több év alatt felhalmozódó elmaradásaként határozták meg.
} 
intézkedés összegének becsléseként - a ciklikusan igazított (elsődleges) egyenleg változását veszi alapul. Ezzel a megközelítéssel egyrészt tartalmi probléma van, hiszen a ciklikus komponens kiszürése révén kihagyják az automatikus stabilizátorokat, amelyeknek pedig van hatása (egyébként értelmük sem lenne). Másrészt módszertani értelemben is számos kritika érte a ciklikus igazítást, többek között a pénzügyi ciklus hatását csak részben szűri ki. Így a ki nem szürt rész maradékalapon belekerül a „diszkrecionális intézkedés” kategóriájába, ezáltal a fiskális politika hatásának becslésénél szisztematikus torzítást okozhat (Guajardo et al. 2011).

A következőkben először az automatikus stabilizátorokkal foglalkozunk, ezután pedig azzal, hogy a ciklikusan igazított (elsődleges) egyenleg módszertanilag miért nem jó közelítése a diszkrecionális fiskális intézkedésnek.

A (6) képlet az egyszerúség kedvéért feltételezte, hogy az adórendszer nem progresszív. A valóságban megfigyelhető progresszív adórendszerek esetében a magas marginális adóráták csökkentik a multiplikátorhatást és ezen keresztül a gazdaság sokkokra való érzékenységét. Musgrave (1959) a progresszív adórendszer ilyen múködését automatikus stabilizátornak (built-in stabilizers) nevezte. Az ilyen értelemben vett szűkebb definíció szerint úgy jelentkezik az automatikus stabilizátorok hatása, hogy a munkanélküliek támogatása $(U)$ és az progresszív adók $(T)$ automatikusan és egységnyit meghaladó mértékben követik a gazdasági teljesítmény $\left(G D P\right.$ ) ingadozását (a két tétel egyenlege legyen $T^{*}=T-U$ ). A stabilizáló képesség időben változó, ahogyan az adórendszer és a szociális támogatások, valamint a demográfia trendje változik (Duesenberry et al. 1960). Fontos megjegyezni, hogy az adók és támogatások nem közvetlenül a GDP alakulását, hanem az adóalapok és munkanélküliség alakulását követik. Mindezek legnagyobb része (pl. lakossági adók és járulékok) időbeni késéssel követik a GDP visszaesését, amennyiben azt a külső kereslet vagy beruházás miatti sokk okozza. Így megfelelő időzítéssel jelentkezik a szúk automatikus stabilizátorok hatása, ami leginkább a lakosság rendelkezésre álló jövedelmének változásán keresztül érvényesül. Ezen hatás mellett az újraelosztási csatorna is szerepet kaphat, nevezetesen, ha a kiadásaikat elköltő háztartások jövedelme nő meg az adófizető/megtakarító háztartások rovására, akkor az aggregált kereslet még inkább nőni fog (Blinder 1975). A progresszív lakossági adóknak emellett stabilizációt biztosító ösztönzési hatása is lehet a munkakínálatra (Christiano 1984).

A fenti három csatorna közül most azzal a meghatározó jelentőségű kérdéssel foglalkozunk, hogy mekkora lehet a szúk automatikus stabilizátoroknak az aggregált keresleten keresztül gyakorolt hatása. Legyen az adóbevétel rugalmassága $\varepsilon$, vagyis $\varepsilon=\frac{\Delta T}{T_{-1}^{*}}: \frac{\Delta Y}{Y_{-1}}$ így a (12) képlet átala-
kítható:

$$
\frac{F I}{Y_{-1}}=\left(\frac{\Delta G}{G_{-1}}-n\right) \frac{G_{-1}}{Y_{-1}}-(\varepsilon-1) \frac{\Delta Y}{Y_{-1}} \frac{T_{-1}^{*}}{Y_{-1}}
$$


Az automatikus stabilizátorok szúk definíciója alapján ez az impulzus azzal egyenlő, amennyivel ezek a tételek az egységnyit meghaladó $(\varepsilon-1)$ mértékben követik a GDP ingadozását.

Az EU egészét tekintve a szúk automatikus stabilizátorok által biztosított fajlagos (egy százalékos GDP változásra eső) fiskális impulzus hivatalos becslése jelenleg 0,229 , amiből az adók progresszivitása 0,171 , a munkanélküli támogatás $0,057^{10}$.

Térjünk át az automatikus stabilizátorok teljes definíciójára. Ez a kamatkiadástól eltekintve minden bevétel és kiadás hatását magában foglalja. Ennek magyarázata, hogy a semleges fiskális politikának is van automatikus stabilizátor hatása. Ha az elsődleges egyenlegből levonjuk a ciklusra reagáló adóbevételt és munkanélküli kiadást, akkor munkanélküli támogatás nélküli elsődleges kiadást és a nem adójellegú bevételeket kapjuk. Ezeket a költségvetés diszkrecionális módon növeli, semleges esetben a potenciális/trend GDP-növekedési ütemével. ${ }^{11}$ Levezethető, hogy a ciklikus komponens akkor egyezik meg a teljes automatikus stabilizáló hatással, amennyiben az elsődleges egyenleg egyensúlyban van. ${ }^{12} \mathrm{Ez}$ az EU szintjén nagyjából igaz, így elvben teljesülhetne, hogy a ciklikus komponens alakulása az automatikus stabilizátor hatáshoz nagyon közel legyen. ${ }^{13} \mathrm{Az} \mathrm{EU}$-ra vonatkozó hivatalos becslések szerint a GDP egy százalékos elmozdulása 0,537 százalékponttal változtatja a ciklikus komponenst (Mourre et al. 2019). Ez azonban két okból sem tekinthető megfelelönek. Egyrészt nem az elsődleges egyenleg tételeit veszi alapul, mert nem korrigál a kamatkiadással. Másrészt az adókat a privát szektor adóival kellene azonosítani (Jedrzejowicz et al. 2009). Ez nemcsak a ciklikus komponenst csökkenti, hiszen adóknál és kiadásoknál történő párhuzamos korrekció miatt egyidejúleg kisebb lesz a szűkebb stabilizátoroknál ((14) képlet) szereplő hatás és a kiadást is figyelembe vevő teljes stabilizációs hatás. Ez azt jelenti, hogy az EU-szintű fajlagos stabilizátor hatás nem a hivatalosan becsült 0,537, hanem körülbelül 0,450 lehet, vagyis a GDP 1 százalékát elérő sokk esetén 45 százalékot ellentételez az államháztartás: ${ }^{14}$ egyrészt az állami adókkal történő nettósítás a szúken vett automatikus stabilizátorok becsült mértékét $(0,229)$ érinti, annak fajlagos mértékét körülbelül 0,190-re csökkentve, másrészt az adókkal szintén nettózott semleges tételek a 0,450-ből még fennmaradó 0,260-os értéket magyarázzák.

\footnotetext{
${ }^{10}$ Mourre et al. (2019) függeléke I. részének táblái alapján

${ }^{11} \mathrm{Az}$ adók esetében nem csupán kulcsok, hanem számos más paraméter is létezik, amelynek változtatása intézkedésnek tekinthető. Ebben a keretben problémát jelent az adórendszer nominális elemeinek (sávok, plafonok stb.) éves valorizációja. Semleges esetben ugyanis a valorizálásra sor kerül, de ez nem intézkedés, hiszen az adóterhelés ezáltal nem változik. A valorizálás elmaradása ugyanakkor adóterhelést növelő intézkedés.

12 P. Kiss (2011:30): 5. keretes írás: „A ciklus fiskális hatása vs. a fiskális politika stabilizáló hatása”

${ }^{13}$ Az EU-nak 2018-ban a GDP 1 százalékát kismértékben meghaladó elsődleges többlete volt, ami minimális torzítást jelent az egyensúly feltételezéséhez képest.

${ }^{14} \mathrm{Az}$ EU szintjén a GDP 33 százalékára tehető az adó és járulékbevétel, ennek negyede/ötöde eredhet állami kiadásból.
} 
Az eddigiekben azt feltételeztük, hogy a ciklikus igazítás megfelelő módon kiszűri a különböző ciklikus ingadozások bevételekre gyakorolt hatását. Ez azonban módszertani okokból nincsen így. A ciklikus igazítás elvégzése után ugyanis egy jelentős és volatilis meg nem magyarázható rész marad (Morris et al. 2009). ${ }^{15}$ Az USA esetében is kimutatható, hogy a ciklikus igazítás nem kezeli az eszközárak ingadozásának hatását (CBO 2013). Az eszközárak az OECD-országok szintjén is torzító hatást gyakorolnak (Price - Dang 2011). Mindez a fiskális politika hatásának becslésénél szisztematikus torzítást okozhat (Guajardo et al. 2011). Az eszközárak pozitív hatását ugyanis nem szűrte ki a ciklikus igazítás, így az egyenlegjavító intézkedésnek látszott, amennyiben az intézkedés meghatározása céljából a ciklikusan igazított elsődleges egyenleg változását vette alapul egy elemzés (ahogy a legtöbben tették). Ha az eszközárak növekedését a kibocsátás növekedése követte, akkor a látszólagos egyenlegjavítás és a növekedés között találhattak összefüggést. Ebben a helyzetben a ciklikus igazítás hagyományos módszereit felválthatta volna a „pénzügysemleges” kibocsátási rés módszere (Borio et al. 2013). A hagyományos „inflációsemleges” módszerek ugyanis több tényezőnek köszönhetően, például a Phillips-görbe torzítása miatt nem működnek megbízhatóan az alacsony inflációs környezetben. Olyan módszertant javasolnak, amely alacsony inflációs környezet mellett is értékelhető és kis revíziójú adatokat eredményez. A szerzők az USA és más országok historikus adataira lényegesen pontosabb adatokat kaptak, mint korábban az OECD, illetve a Nemzetközi Valutaalap. A világgazdasági válság előtt a valós idejű adatok azt mutatták, hogy az USA, az Egyesült Királyság és Spanyolország gazdaságát a választott módszertantól függően negatív, vagy legfeljebb zárt kibocsátási rés jellemezte, az ex post felülvizsgálatok azonban rávilágítottak a hagyományos módszertanok hiányosságaira. A Borio és szerzőtársai (2013) által kidolgozott modell, mely az ingatlanárak és a hitelaggregátumok növekedésén keresztül a pénzügyi ciklusok felépülését is számításba veszi, jelentős pozitív kibocsátási rést mutat mind a valós idejű adatokat, mind a visszatekintő módszert figyelembe véve. Emellett az utólagos revízió mértéke is minimálisra csökken. Értékelésük szerint, míg az üzleti ciklusok legfeljebb 8 évig tartanak, addig a pénzügyi ciklusok jellemzően 16-20 évente váltakoznak. A Borio és szerzőtársai (2013) által jegyzett kutatás eredményeire is építve Bernhofer és szerzőtársai (2014) is azt találták, hogy a kibocsátási rés hagyományos (inflációsemleges) módszerei nem tudják jelezni a pénzügyi ciklusok miatti fellendülést. A korábbi kutatáshoz képest újdonság, hogy a szerzők a GDP trendjét és ciklikus változását is különválasztják a modellben, illetve két országcsoportot, egy fejlődőt és egy fejlettet is vizsgálnak. Az új módszertannal számolva a GDP ciklikus komponense az országok többségében számottevően magasabb volt a válságot

\footnotetext{
${ }^{15}$ A profitadók 1999-2000-ben és 2004-2007-ben extra adóbevételt (windfall), 2001-2003-ban pedig extra adókiesést okozott (shortfall) Németországban, Spanyolországban, Franciaországban, Olaszországban és Hollandiában. Ennek oka a veszteségleírások mellett az átértékelődésből eredő profit alakulása volt. A ciklikus igazítás nem terjed ki a lakásberuházásra, így az indirekt adókból csak a fogyasztás ciklusa került kiszűrésre. Ez Írországban és Spanyolországban okozott meg nem magyarázott maradékot.
} 
megelőző időszakban, mint a hagyományos módszerekkel számított ciklikus komponens értéke. A potenciálist érdemben meghaladó valós kibocsátást országtól függően az ingatlanárak növekedése, a hitelezési folyamatok felfutása, vagy a két tényező együtt eredményezte. A következő fejezetben bemutatjuk a kibocsátási rés torzított becslésének következményeit.

\section{A potenciális/trend GDP valós idejü bizonytalansága}

Láttuk, hogy az $n$ egyensúlyi paraméter a (10) képlet meghatározó tényezője és így az automatikus stabilizátorok teljes definíciójának, valamint az így számított semleges pályához képest definiált diszkrecionális intézkedésnek is kulcseleme.

Több vizsgálat (Forni - Momigliano 2005, Cimadomo 2008, Borio et al. 2013, Bernhofer et al. 2014) kimutatta, hogy a kibocsátási rés becslése valós időben, tehát amikor a fiskális politikai döntéseket meghozták, jelentősen eltért attól, amit a később bekövetkező folyamatok alapján lehetett becsülni. A kibocsátási rés későbbi revíziói abból eredtek, hogy a potenciális növekedésről alkotott kép utólag rosszabb lett, így egy korábban pozitívnak tűnő kibocsátási rés utólag már negatívnak bizonyult (1. táblázat). Ennek következménye ez lett, hogy számos országban az 1994 és 2006 között anticiklikusnak szánt fiskális politikáról utólag bizonyosodott be, hogy az prociklikus lehetett (Caudal et al. 2013, Forni-Momigliano 2005, Cimadomo 2008, P. Kiss 2017). A potenciális GDP becslését a válság előtt felfelé torzíthatta, hogy az üzleti ciklusok mellett megjelent a pénzügyi ciklus is (Borio et al. 2013, Bernhofer et al. 2014). Rogoff (2016) felhívja a figyelmet arra, hogy a pénzügyi ciklus következtében jelentős volt a tőkeáttétekkel kísért lakásbuborék és kipukkanásának nagysága, valamint a válság előtti és utáni eszközárváltozások mértéke. Boone és Buti (2019) mellett Benoît Coeuré (2017) is rámutat arra, hogy a potenciális GDP becslése lefelé történő revíziójának a hiszterézis jelenségétől függetlenül is trendje van. ${ }^{16}$

16 „These effects have been taken by many as evidence for hysteresis. But the discussion is arguably more complex than this. For sure, potential output estimates are chronically unreliable and often subject to substantial revisions ex post. [...] P(p)otential output growth had been slowing in the euro area well before the crisis, mainly reflecting a long-term slowdown in total factor productivity (TFP)." (Cœuré 2017) 


\section{1. táblázat \\ Adott év kibocsátási résének becslése megelőző évben és 2019-ben (a GDP százalékában)}

\begin{tabular}{l|c|c|c|c|c|c|c|c}
\hline Év & \multicolumn{2}{|c|}{$\mathbf{2 0 0 0}$} & \multicolumn{2}{c|}{$\mathbf{2 0 0 1}$} & \multicolumn{2}{c|}{$\mathbf{2 0 0 2}$} & \multicolumn{2}{c}{$\mathbf{2 0 0 3}$} \\
\hline Publikáció & $\mathbf{1 9 9 9}$ & $\mathbf{2 0 1 9}$ & $\mathbf{2 0 0 0}$ & $\mathbf{2 0 1 9}$ & $\mathbf{2 0 0 1}$ & $\mathbf{2 0 1 9}$ & $\mathbf{2 0 0 2}$ & $\mathbf{2 0 1 9}$ \\
\hline Ausztria & 0,6 & 1,6 & $-0,5$ & 0,4 & $-1,1$ & $-0,1$ & $-0,4$ & $-1,3$ \\
\hline Belgium & $-2,0$ & 1,8 & 0,8 & 0,5 & $-0,3$ & 0,0 & $-0,4$ & $-1,0$ \\
\hline Dánia & $-2,9$ & 2,7 & 0,0 & 1,4 & 0,4 & 0,2 & $-0,1$ & $-0,7$ \\
\hline Finnország & $-2,2$ & 2,9 & 1,0 & 1,3 & 1,8 & $-0,4$ & $-0,3$ & $-1,6$ \\
\hline Franciaország & $-2,7$ & 2,2 & 1,8 & 2,2 & $-0,6$ & 1,6 & $-0,3$ & 0,7 \\
\hline Németország & $-0,1$ & 1,4 & $-0,1$ & 1,7 & $-1,5$ & 0,3 & $-1,4$ & $-1,6$ \\
\hline Görögország & $-0,2$ & 1,3 & 1,3 & 1,3 & 2,2 & 1,2 & 1,8 & 2,2 \\
\hline Írország & 0,3 & 4,5 & 1,5 & 2,2 & 0,2 & 1,4 & $-1,4$ & $-1,2$ \\
\hline Olaszország & $-2,3$ & 1,9 & $-2,4$ & 2,4 & $-0,9$ & 1,5 & $-1,3$ & 0,7 \\
\hline Luxemburg & $-2,1$ & 5,9 & $-1,1$ & 3,4 & $-3,0$ & 2,9 & 0,0 & 0,3 \\
\hline Hollandia & $-3,3$ & 2,4 & 2,0 & 1,6 & $-1,1$ & $-0,6$ & $-1,8$ & $-2,4$ \\
\hline Portugália & 0,1 & 3,0 & $-1,0$ & 2,1 & $-1,5$ & 0,8 & $-2,8$ & $-1,5$ \\
\hline Spanyolország & $-3,2$ & 3,0 & 0,1 & 3,5 & $-0,9$ & 2,9 & $-1,5$ & 2,3 \\
\hline Svédország & $-0,9$ & 1,7 & 0,3 & 0,0 & 0,7 & $-0,8$ & $-0,1$ & $-1,4$ \\
\hline Egyesült Királyság & $-0,8$ & 1,1 & 1,2 & 0,9 & $-1,0$ & 0,2 & $-0,9$ & 0,7 \\
\hline
\end{tabular}

Megjegyzés: Kék szín: az előjelet eltalálták, piros szín: az előjelet sem találták el.

Forrás: EC (1999, 2000, 2001, 2002) és AMECO

A 4. ábra azt szemléleti, hogy a kibocsátási rés valós idejű bizonytalansága milyen problémát okoz a fiskális politika megfelelő irányultságának kialakításában, még abban az esetben is, ha a cél csak annyi lenne, hogy „hagyjuk az automatikus stabilizátorokat működni”. Az ábrán valós időben a kiadás semleges ütemű („,no-policy-change") növekedése megegyezik az adóbevétel trendjével, ami intézkedés nélkül a gazdasági növekedés ütemét követi. ${ }^{17}$ Amennyiben egy jelentős visszaesést követően utólag kiderül, hogy a növekedés és így az adóbevételek trendjét lefelé kell korrigálni (szaggatott kék vonal), akkor az ezzel konzisztens semleges kiadási pálya (szaggatott zöld vonal) is változik. Ekkor válik csak nyilvánvalóvá, hogy a semlegesnek szánt kiadás végig expanzív volt; az expanzió kumulált mértéke a szaggatott és teljes zöld vonalak különbsége (a szándékkal ellentétben nem hagyták az automatikus stabilizátorokat múködni). A magasabb ciklikusan igazított hiány ebben az esetben azt jelzi, hogy a kiadás magasabb a semleges szintnél, ezért valamikor - lehetőség szerint nem a válság idején - ki kell majd igazítani. Ha a válság idején további

\footnotetext{
${ }^{17}$ A diszkrecionális kiadás definíciójához viszonyítási alapként szükség van a semleges kiadási növekedés meghatározására. A tényleges kiadási pálya így minden időpontban kettéválasztható egy semleges és diszkrecionális részre.
} 
anticiklikus, lazító intézkedések is történnek, akkor ez a fellendülés idejére halasztott kiigazítás még nagyobb lesz. Itt azonban, ahogy a bevezetésben is említettük, a fenntarthatóság szempontja - magas adósságráta esetén - ellentétbe kerülhet a stabilizációs funkcióval.
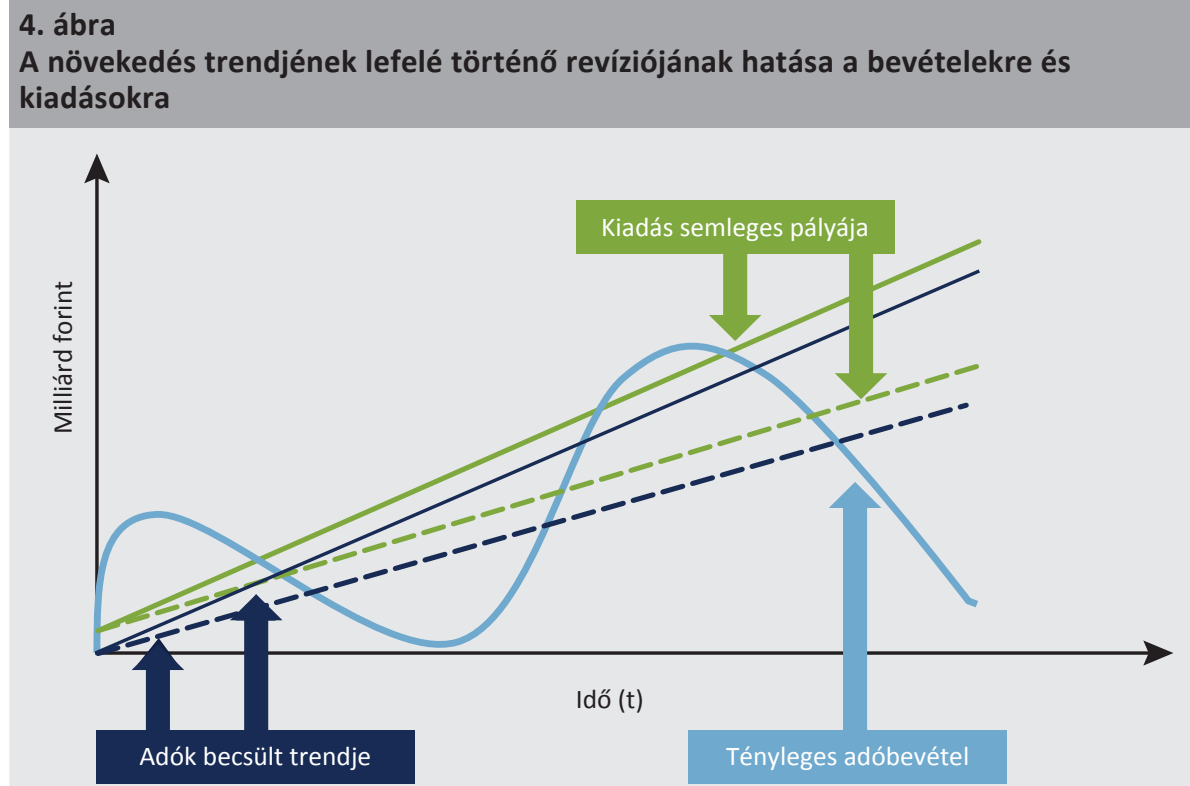

\section{Stabilizáció egy monetáris unióban; automatikus stabilizátor és diszkrecionális intézkedés}

Egy monetáris unió tagállamainak a saját fiskális politika áll rendelkezésre gazdasága stabilizálásához, hiszen az árfolyam-alkalmazkodás a monetáris unión belül már nem lehetséges, a relatív árak korrekciója pedig lassabb folyamat. Egyedi, egyes országokat érő negatív sokkok esetén a monetáris unión belüli kockázatmegosztás is hozzájárulhat a stabilizáláshoz. Ennek egyik eleme a helyi szintű jövedelem és fogyasztás közötti kapcsolat gyengítése az integrált tőkepiacon keresztül, a másik pedig a helyi hitelkínálat és a helyi bankok tőkéje közötti kapcsolat megbontása a bankszektor integrációjával. E két tényező az Egyesült Államokban a helyi sokkok 70 százalékát, míg az euroövezetben csak 25 százalékát semlegesíti (Nikolov 2016). Az euroövezetben korábban még prociklikusság is jelentkezett, a jó időkben országok közötti hitelnyújtást, rossz időkben visszafizetést eredményezve (Albertazzi - Bottero 2014). Az Öt Elnök Jelentése (Juncker et al. 2015) ezért jelölte meg időben második célként a pénzügyi unió megteremtését, aminek részeként egységes bankfelügyelet, egységes bankszanálás (Single Resolution Fund, Single Resolution Mechanism), 
egységes betétbiztosítás (European Deposit Insurance Scheme) és tőkepiaci unió jöhet létre. A makroprudenciális politika azért is fontos, mert amennyiben megfelelően célzott, akkor csökkentheti az alacsony kamatok mellékhatásait (Draghi 2019).

Ezen tényezők potenciális stabilizáló hatásához képest a tagállamok közötti fiskális transzferek jelentősége nagyságrenddel kisebb lehet. Még az olyan jelentős fiskális föderalizmust kialakító országokban is, mint az Egyesült Államok, csak a sokkok 10 százalékát semlegesítik az államoknak nyújtott fiskális transzferek (Nikolov 2016). Dreyer és Schmid (2015) megmutatta, hogy az USA rendszeréhez hasonló mértékű stabilizáció és újraelosztás sokkal nagyobb transzfert igényelne az euroövezet országai között. Az Öt Elnök Jelentése (Juncker et al. 2015) időben harmadik célként tűzte ki a költségvetési unió létrehozását. Olyan - automatikus stabilizációnak nevezett - eszközt vezetnének be az euroövezetben, amelynek célja nem a teljes övezet szintjén történő stabilizáció, hanem általában a sokkok hatásának enyhítése. Ez azonban nem eredményezheti azt, hogy állandó jellegű, egyirányú transzferek keletkezzenek tagállamok között, mert nem lehet az országok közötti jövedelemkiegyenlítés eszköze. Nem váltaná fel az európai stabilitási mechanizmust (ESM), ami fennmarad válságkezelési eszköznek, hanem annak igénybevételének megelőzésére szolgálna. Az azóta született javaslatok kormányok közötti transzfereket használnának. Olyan alapba fizetnének be a tagállamok, amiből automatikusan kaphatnak transzfert a makrogazdasági változóik alakulásának függvényében. A forrásfelhasználásban eltérnek a javaslatok, van, amelyik a háztartásoknak adna transzfert (munkanélküli ellátás), és van, amelyik állami beruházásra fordítaná. Az előbbi egy gazdasági visszaesésre azonnal tudna reagálni, azaz a munkanélküliség növekedésével párhuzamosan tudna forrást juttatni a háztartásokhoz. Az utóbbi késve tud csak reagálni egy visszaesésre, mivel a gazdasági mutatók mérése időben eltolódhat, illetve az állami beruházások előkészítése hosszan tartó folyamat lehet.

A 4. fejezetben szereplő definíciók szerint csak a munkanélküli ellátás minősíthető automatikus stabilizátornak, a többi diszkrecionális intézkedésnek. Szúk értelemben a progresszív adórendszer és a munkanélküli támogatások, teljesebb értelemben a stabilan tartott kiadások jelentenek automatikus stabilizátort, utóbbi elem az euroövezet egészét érő sokkokat semlegesítené, nem az egyes tagállamok szintjén jelentkező sokkokat.

Az EU közös költségvetése a bevételi oldalon nem progresszív, és nem követi automatikusan a ciklust ${ }^{18}$, míg a kiadások jelentősebb részét kitevő strukturális támogatások nem simák. A hétéves programoknak megfelelően ingadoznak, így véletlenszerű, hogy anticiklikus vagy prociklikus hatású diszkrecionális intézkedésnek felelnek meg. A közös költségvetés mérete az EU GDP-jének 1 százaléka körül van, így jelenleg sem elvben, sem gyakorlatban nem tekinthető stabilizációs tényezőnek.

\footnotetext{
${ }^{18}$ A GNI előző évi alakulása alapján azonban alkalmaznak korrekciókat a tagállamok befizetésében.
} 
Tegyünk egy gondolatkísérletet arra, hogy a jövőben esetleg mi változhatna. Egyrészt a közös költségvetés centralizálhatna már létező tagállami kiadásokat (az azokat fedező bevétellel együtt). A legnagyobb tagállami tételek az adminisztráció, oktatás, egészségügy, nyugdíjak, munkanélküli- és családtámogatás, valamint a vállalati támogatások. Ezek közül egyik tétel központosítása sem indokolt. A védelmi kiadások központosítása sem reális, de itt minimális összeg elképzelhető. A környezetvédelmi és K+F-támogatásoknál nem zárható ki egy részleges centralizáció, de az egész öszszeg reálisan a GDP 1 százaléka alatt maradna. Másrészt a közös költségvetés találhatna addicionális kiadásokat, ehhez azonban addicionális források is szükségesek, vagyis az EU szintjén növelni kellene az adókat hozzá. ${ }^{19}$ Folytatva a gondolatkísérletet, ezek a kiadások lehetnének a korábban említett, stabilizációs célú támogatások, amihez talán egy GDP 1 százaléka körüli összeg elegendő lehet. Összességében maximum 3 százalékra nőne a közös költségvetés, amiből a stabil kiadások a GDP 1 százalékát érnék el, másik 1 százalék a hétéves támogatási programnak megfelelően ingadozna, és az addicionális 1 százalék stabilizációs támogatás lehetne anticiklikus. Ennek megfelelően, amíg az EU-tagállamok szintjén 1 százalék visszaesés esetére 0,537-os fajlagos stabilizátor hatás becsülhető (lásd 4. fejezet), addig a közös költségvetés 1 százalékos anticiklikus részének stabilizációs hatása 0,010 lenne. Gondolatkísérletünk eredményének tehát láthatóan nem lenne érzékelhető stabilizációs szerepe. Egy EU-szinten 1 százalékos diszkrecionális stabilizációs kiadás ugyanakkor a támogatásban részesülő országok szintjén akár a GDP 4-5 százalékának megfelelő anticiklikus intézkedést is fedezhetne.

\section{Fiskális politikai koordináció és strukturális reformok}

Az eddigiekben azzal az aggregált stabilizációs politikával foglalkoztunk, amely a kereslet általános bővítésén vagy szúkítésén keresztül valósul meg. A következőkben a célzott intézkedéseket tárgyaljuk, beleértve azt a speciális esetet, amikor egyenlegsemleges módon, a bevétel-kiadás szerkezetet változtatva valósulnak meg. A célzott intézkedések kapcsolódhatnak strukturális reformokhoz is, amelyekről szintén lesz majd szó.

Bevezetésképpen a koordináció kérdését vizsgáljuk. Az európai szemeszter célja az volt, hogy erősítse a tagállamok közötti gazdaságpolitikai koordinációt, ahogyan azonban az Öt Elnök Jelentése (Juncker et al. 2015) is rámutatott, a számos elöírás és eljárás túl bonyolult volt, és nem eléggé hatékony. Az ajánlásoknak azokra a strukturális reformokra kellene irányulniuk, amelyek az egységes piac hatékonysága és a potenciális gazdasági növekedés növelése érdekében szükségesek. Az államháztartási

\footnotetext{
${ }^{19}$ Egy európai közös munkanélküli ellátó rendszer, amely kiegészítené a nemzeti munkanélküli ellátó rendszereket stabilizációs szempontból jól múködő lehetne, azonban az eltérő rendszereket múködtető tagállamok szintjén torzításokhoz vezethetne. Nemcsak az addicionális összegek lennének arányaiban eltérők, hanem az ellátás időtartama is jelentősen különbözhetne.
} 
egyenleg és az annak változásán keresztül megvalósuló aggregált stabilizációs politika jelentősége tehát több okból csökken. A strukturális reformok mellett egyre inkább a fiskális politika szerkezete kerül előtérbe, továbbá a makro-egyensúlytalansági eljárás keretében olyan szempontok is megjelentek, mint az ingatlanbuborékok megelőzése, valamint a versenyképesség csökkenésének, a magán- és államadósság növekedésének és a beruházások elégtelen mértékének korai felismerése, amelyek célzott reformokat igényelhetnek.

Fontos az okok felismerése, hiszen például a konkrét lépések attól függnek, hogy egy gazdasági visszaesés hátterében milyen tényezők állnak. A Magyar Nemzeti Bank 2015. évi növekedési jelentése (MNB 2015) áttekintette a válság hátterében álló potenciális okokat. Ezek közül a pénzügyi tényezők jellemzően átmeneti - bár elhúzódó - hatást gyakorolnak a gazdasági növekedésre. Ezeknek a problémáknak az enyhítése érdekében általános vagy célzott keresletbővítésre lehet szükség ( 2 . táblázat).

\section{2. táblázat}

Fiskális reakció a gazdaság ciklikus problémáira

\begin{tabular}{l|l}
\multicolumn{1}{c|}{ Mérlegválság } & \multicolumn{1}{c}{ Anticiklikus fiskális politika } \\
\hline lehetséges pénzügyi okok: & lehetséges fiskális lépések: \\
- hitelezés felfutása & - általános keresletbővítés \\
- túlzott eladósodás & - célzott keresletbővítés: \\
- mérlegek kiigazítása & • tőketranszferek \\
- szektorális reallokáció & •állami beruházások \\
\hline
\end{tabular}

Forrás: MNB (2015) alapján szerkesztve

A 2015. évi növekedési jelentés arra is felhívta a figyelmet, hogy tartós, reálgazdasági problémák is lehetnek a válság hátterében. A 3. táblázat összefoglalja a lehetséges okokat, és a kezelésükre alkalmas célzott intézkedéseket.

\section{3. táblázat}

Fiskális reakció a tartós stagnálás esetére

\begin{tabular}{l|l}
\multicolumn{1}{c|}{ Tartós stagnálás } & \multicolumn{1}{c}{ Tartós fiskális reformok } \\
\hline $\begin{array}{l}\text { lehetséges reálgazdasági okok: } \\
\text { - kedvezőtlen demográfia } \\
\text { - elégtelen innováció }\end{array}$ & $\begin{array}{l}\text { lehetséges fiskális lépések: } \\
\text { - mérséklődő beruházás } \\
\text { - a kevésbé termelékeny szolgáltatási szektor } \\
\text { súlya nő }\end{array}$ \\
$\begin{array}{l}\text { - munkajövedelmek súlya csökken, } \\
\text { egyenlőtlenség nő }\end{array}$ & $\begin{array}{l}\text { - állami szerepvállalás, támogatás } \\
\text { - oktatás }\end{array}$ \\
\hline Forrás: $M N B$ (2015) alapjánán szerkelem-újraelosztás \\
\hline
\end{tabular}


A koordináció részeként az EU makro-egyensúlytalansági eljárása (MIP) többek között a szektorok pozíciójával és a kereskedelmi többlet problematikus mértékével is foglalkozik (EC 2016). Az okok feltárása érdekében azonban elemzéseikben a puszta azonosságok mögé néznek, így tettek például különbséget Németország és Svédország között. ${ }^{20}$

Az euroövezet szintjén az infláció természetes rátájának csökkenése azonos okok és következmények melletti közös kihívás, ami szintén az országok közötti koordinációt igényli. Ahogy Draghi (2019) fogalmaz, a monetáris politika az infláció természetes rátáját adottságként kezeli, ezért az alacsony rátát szintén a fiskális és strukturális politika emelheti. A strukturális politika felgyorsíthatja az erőforrások allokációjának változását és az innovációt, ami a teljes tényezőhatékonyságot (TFP) növeli. A fiskális politikának a szerkezete számít, az oktatási és hatékony állami beruházási kiadás a termelékenységet növeli, egyes intézkedések pedig a jövedelemegyenlőtlenséget csökkentik, és a foglalkoztatottságot növelik. Becslések szerint mindez megelőzheti az infláció természetes rátájának csökkenését (Rachel - Summers 2019). A produktív kiadások (infrastrukturális beruházás, $\mathrm{K}+\mathrm{F}$ és oktatás) aránya szinte minden euroövezeti országban csökkent a válság óta (EFB 2019). EKB-becslések szerint egy koordinált beruházási kiadásnak hatszor akkora lenne a szétterjedő hatása az euroövezetre, ha válaszként a jegybank nem emeli a kamatokat (Alloza et al. 2019).

Az EU költségvetési szabályai és makro-egyensúlytalansági eljárása egyaránt fontos szerepet tulajdonít az állományi változóknak. Válság esetén problémaként jelentkezhet ugyanis, hogy nincsen költségvetési mozgástér abban a szűkebb értelemben, hogy az adósság (és deficit) nem növelhető. Fenntarthatósági probléma esetén nincs lehetőség hiánynövelő, anticiklikus fiskális politikára, sőt, hiánycsökkentő intézkedésekre lehet szükség. A részletek (célzottság/hatékonyság) fontossága azonban éppen ekkor mutatkozik meg a legnyilvánvalóbb módon. A mozgástér legáltalánosabb definíciója (Heller 2005) szerint a szándékolt kiadásnövelő vagy adócsökkentő intézkedések nem csupán a hiány/adósság terhére valósíthatók meg. Forrásuk lehet adóemelés (pl. tax shift), az adóbeszedés hatékonyságának javítása, alacsony prioritású kiadások csökkentése, seigniorage-bevétel vagy külföldi (pl. EU-) transzferek. Szembeállítható az aggregált stabilizációs politika és a célzott intézkedések, azon belül is az egyenlegsemleges reformok esete.

${ }^{20}$ 2014-ben ugyanis mindkét országban jelentős és hasonló mértékű külkereskedelmi többlet volt. Svédországban ugyanakkor a nettó nemzetközi befektetési pozíció kiegyensúlyozottabb volt, mint Németországban, így utóbbi esetben a folyó fizetési mérleg többletét makro-egyensúlytalanságnak minősítették, szemben az előbbi esettel. 
Az egyik álláspont szerint a tartósan alacsony kereslet idején az általános keresletbővítés jó eszköz; költségeik miatt nem érdemes választani a strukturális reformokat. Magas adósság mellett van kockázata a lazításnak, de ez megváltozik komolyabb válságidőszak esetén. Ilyenkor igaz lehet, hogy egy monetáris unión belül az eladósodott országok bekapcsolása a koordinált lazításba az előnyök oldalán negatív hatású, de a költségek oldalán még nagyobb ez a negatívum, vagyis kihagyásuk költsége magasabb, mint a bevonásuk kockázatából származó költség. Becslés szerint e két hatás eredőjeként a kihagyásuk a GDP-re gyakorolt első éves pozitív hatást kétharmadával csökkentené (Triggs 2018). Azok a strukturális reformok, amelyek az inflációt csökkentik, ezzel szemben rövid távú gazdasági költségekkel járhatnak válság idején, mert azt a ZLB (zero lower bound) idején a monetáris politika nem tudja ellensúlyozni (Eggertsson et al. 2014)

A másik vélemény szerint a tartósan alacsony kereslet idején inkább célzott intézkedésekre van szükség, adott esetben egyenlegsemleges módon, valamint a strukturális reformok közötti prioritás felállítására (OECD 2016, Boone - Buti 2019). Egyrészt hatékony lehet az olyan infrastrukturális beruházás, amely összhangban van az EU fiskális keretrendszerével (OECD 2016, Boone - Buti 2019), másrészt olyan növekedést segítő fiskális reformokra van szükség, amelyeknek rövid távú pozitív hatása is lehet, ilyen például a lakástámogatás, az álláskeresés régiók és szakmák közötti elősegítése, vagy a szolgáltatási szektorba történő belépés akadályainak lebontása (OECD 2016, OECD 2019b).

Végül a hiány szempontjából kismértékű mozgástérrel rendelkező országok alacsony költségű reformokat (OECD 2016) hajthatnak végre, vagy akár egyenlegsemleges fiskális lépéseket olyan módon, hogy azok csak az adók összetételét és a kiadási szerkezetet változtatják, miközben a deficit változatlan marad. Ez összhangban van azzal a megfigyeléssel, hogy a különböző diszkrecionális intézkedések multiplikátora nagyon eltérő. A francia jegybank több országot tartalmazó DSGE-modelljének szimulációi szerint a beruházások növelése kevésbé torzító adókkal mind a rövid, mind a hosszú távú növekedést emeli, ezáltal javítja a fenntarthatóságot. Azt is találták, hogy az egyenlegsemleges reformoknak az országok közötti szétterülő hatása nem nagy, amennyiben azonban koordinált és a monetáris politika nem reagál, akkor növekedhet a hatás (Bussière et al. 2017).

Modellszámítások rendelkezésre állnak a 2010-et követő egyenlegsemleges magyar intézkedések hatására vonatkozóan is. Az adóreform része volt a munkát terhelő adók csökkentése, a családpolitikai célokat szolgáló családi adókedvezmény és a vállalkozások támogatását célzó adócsökkentés. A fogyasztási adók emelése és a pénzügyi, kiskereskedelmi, telekommunikációs és energiaszektort érintő válságadók kivetése révén az adók súlypontja áthelyeződött a termelésről a fogyasztásra. Az adócsökkentést részben a kiadási oldalon ellentételezték; a táppénzt, a korhatár alatti és a rokkantnyugdíjakat mérsékelték. A munkaerőpiaci aktivitás 
emelkedéséhez hozzájárult az is, hogy a munkanélküli ellátások helyett munkalehetőséget biztosítottak. ${ }^{21}$ Becslések szerint az adócsökkentő és adóemelő intézkedések hosszabb távon pozitív hatást gyakorolnak a gazdaságra (Palotai 2017, Baksay - Csomós 2014). Egy másik, nagyobb adóintézkedéseket és a transzferváltozásokat vizsgáló szimuláció (Szoboszlai et al. 2018) szerint a 16 százalékos szja bevezetése hosszú távon 3 százalékkal növelte az effektív munkakínálatot, amit nagyobb részben az intenzív oldali alkalmazkodás okoz, 0,6 százalék pedig a foglalkoztatásbővülés eredménye. Ennek következtében a negatív költségvetési hatás hosszú távon ötödére csökkenhet. A szuperbruttó adóalap kivezetése hasonló mértékben csökkentette az adóterhelést, ez az intézkedés hosszú távon 1,5 százalékkal növelheti a foglalkoztatást, így a hiányra gyakorolt azonnali negatív hatás ebben az esetben kétharmadára csökkenhet. A nagyobb adó- és transzferintézkedéseket 2008 és 2013 között vizsgálta Benczúr et al. (2018). 2008-2010 között azt találták, hogy a hosszú távú GDP és foglalkoztatottság nőhetett, de intenzív oldali alkalmazkodás nélkül. 2010-2013 között ezzel szemben jelentős pozitív hatást eredményezhetett az intenzív oldali alkalmazkodás, a foglalkoztatottság növekedését azonban inkább a munkanélküli támogatás csökkenésével kapcsolták össze.

Az euroövezet egészét tekintve az OECD becslése szerint 2007 és 2017 között 0,2 százalékkal volt kisebb a TFP hozzájárulása a potenciális növekedéshez, mint a válság előtti időszakban. Ezért olyan intézkedéseket javasoltak, amelyek öt éven keresztül évi 0,2 százalékkal növelnék a TFP-t, és az 1 százalékkal magasabb szint ezt követően állandó maradna. Az 5. ábra azt mutatja, hogy az euroövezetben ezek a strukturális lépések és a koordinált fiskális politika hogyan hatna a GDP-re az OECD NiGEM-modell segítségével készített becslésének eredményei alapján. Ez az alappályához mért szintbeli eltérést mutatja, és látható, hogy a szűk értelemben vett fiskális politika hatásossága csekély és átmeneti a strukturális politikához képest (OECD 2019a: 1.4. keretes írás).

${ }^{21} 2010$-et követően a foglalkoztatottak száma mintegy 740 ezer fővel nőtt, ezáltal a foglalkoztatási ráta az EU-átlag közelébe került. 


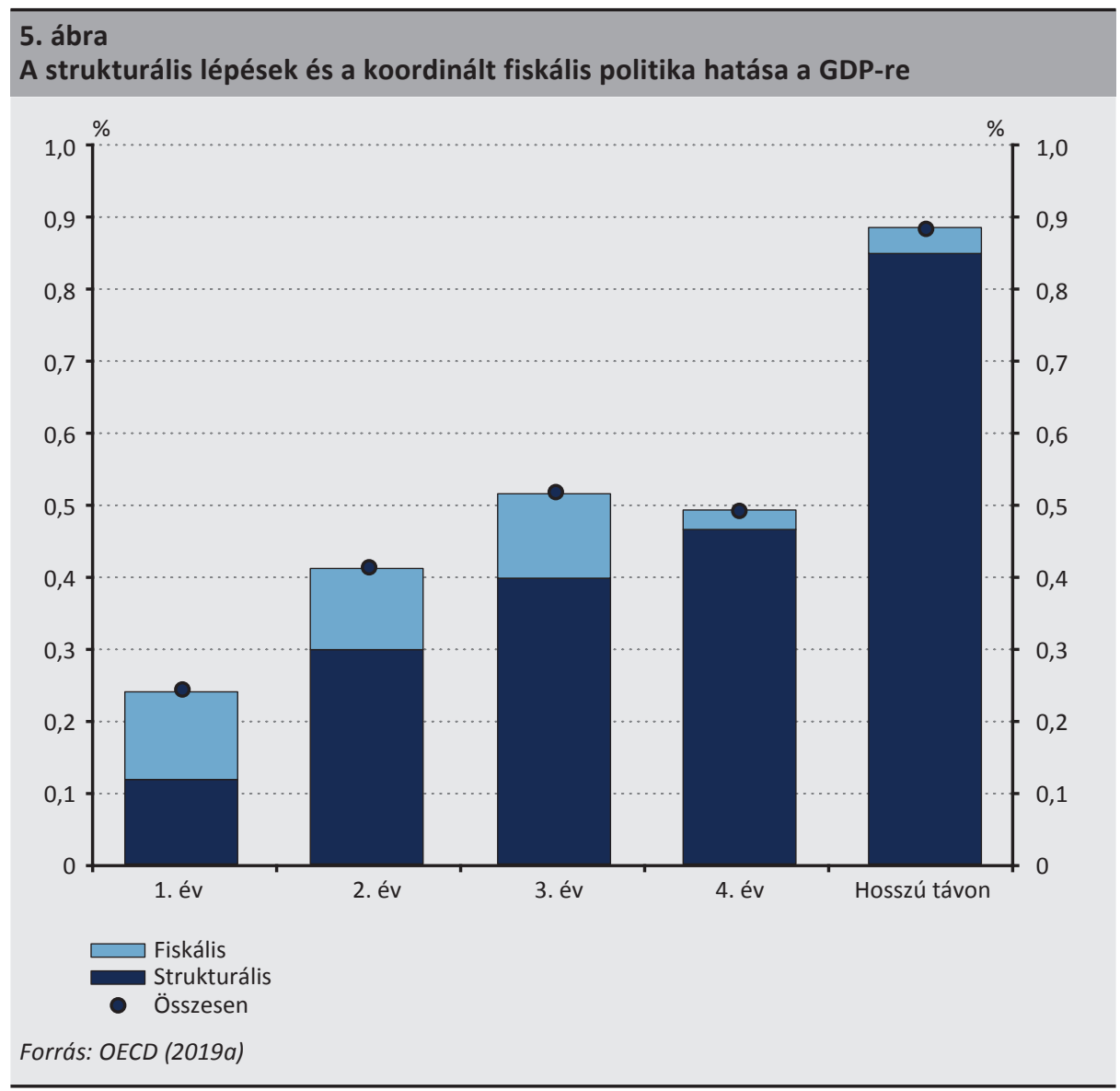

\section{Következtetések}

Korábban a gazdaságpolitika két alappillérének a hagyományos eszköztárral rendelkező monetáris politikát és az aggregált fiskális keresletbővítést tekintették. A válságot követően nem csupán a monetáris politika eszköztára bővült, hanem újabb pillérek is megjelentek, nemcsak állami szinten, hanem az EU-n és euroövezeten belüli koordinációban is. A stabilizálás feladata mellett ugyanis a potenciális gazdasági növekedés és az egységes piac hatékonyságnak növelésére is szükség van. Mindezt célzott fiskális intézkedések mellett strukturális és versenyképességi reformok, továbbá makro- és mikroprudenciális eszközök támogathatják. Az EU makro-egyensúlytalansági eljárásának keretében megjelentek célzott reformokat igénylő szempontok is, mint az ingatlanbuborékok megelőzése, valamint a versenyképesség csökkenésének, a magán- és államadósság növekedésének és a beruházások hiányának korai felismerése. 
Egy monetáris unió esetében a saját fiskális politika (általános keresletbővítés vagy célzott intézkedés) stabilizálhatja a tagállamok gazdaságát, hiszen árfolyam-alkalmazkodásra nincs mód, a relatív árak korrekciója pedig lassú. A stabilizációs célú fiskális politika hatékonyságát jelentősen rontja, hogy a kibocsátási rés becslése valós időben, tehát amikor a döntéseket meghozzák, jelentősen eltért attól, ami később a tények teljes körének ismeretében látszik. Megmutattuk, hogy a revízió következményeképpen 2000 és 2003 között az EU-tagállamok felében okozhatott problémát a kibocsátási rés előjelének megváltozása, vagyis egy anticiklikusnak szánt fiskális politikából prociklikus lehetett.

Szimulációval bemutattuk, hogy egy tartós és nagymértékủ általános fiskális keresletbővítés a rövid távú előnyök ellenére költséges, vagyis adósságrátát növelő lehet, akár gyenge keynesiánus, akár újklasszikus multiplikátorokat feltételezünk. Sajátos helyzetben (hiszterézis) tartósan magasabb multiplikátorok adódhatnak, azonban ezek szélsőértékei sem elegendők ahhoz, hogy a lazítás ne emelje nagymértékben az adósságrátát, vagyis az önfinanszírozás a magasabb GDP-vel sem lehetséges. Ilyen értelemben mondhatjuk, hogy tartós és jelentős problémák esetén az általános keresletbővítés nem csodaszer. Az OECD szimulációi szerint ennek alternatívája, a strukturális reform alkalmasabb eszköz a GDP tartós növelésére, vagyis kevésbé költséges lehet. Hasonló eredményeket kaptak a célzott intézkedésekre vonatkozó magyar tapasztalatokat feldolgozó szimulációk.

\section{Felhasznált irodalom}

Albertazzi, U. - Bottero, M. (2014): Foreign Bank Lending: Evidence from the Global Financial Crisis. Journal of International Economics, 92(Supplement 1): S22-S35. https://doi. org/10.1016/j.jinteco.2014.01.002

Alloza, M. - Cozmanca, B. - Ferdinandusse, M. - Jacquinot, P. (2019): Fiscal spillovers in a monetary union. ECB Economic Bulletin, Issue 1. https://www.ecb.europa.eu//pub/ economic-bulletin/articles/2019/html/ecb.ebart201901_02 5a37c33119.en.html

Auerbach, A.J. - Gorodnichenko, Y. (2012a): Fiscal multipliers in recession and expansion. In: Alesina, A. - Giavazzi, F. (eds.): Fiscal Policy after the Financial Crisis. Chicago, University of Chicago Press, pp. 63-98. https://doi.org/10.7208/chicago/9780226018584.003.0003

Auerbach, A. J. - Gorodnichenko, Y. (2012b): Measuring the Output Responses to Fiscal Policy. American Economic Journal: Economic Policy, 4(2): 1-27. https://doi.org/10.1257/pol.4.2.1

Baksa Dániel - Benk Szilárd - Jakab M. Zoltán (2014): Létezik „a” költségvetési multiplikátor? Fiskális és monetáris reakciók, hitelesség és költségvetési multiplikátorok Magyarországon. Szigma, 45(1-2): 57-84. 
Baksay Gergely - Csomós Balázs (2014): Az adó- és transzferrendszer 2010 és 2014 közötti változásainak elemzése viselkedési mikroszimulációs modell segítségével. Köz-Gazdaság, 9(4): 31-60.

Barry, F. (1991): Irish Recovery 1987-90: Economic Miracle? Irish Banking Review, 1991(Winter): 23-40. https://core.ac.uk/download/pdf/16338738.pdf. Letöltés ideje: 2020. március 5.

Batini, N. - Eyraud, L. - Forni, L. - Weber, A. (2014): Fiscal Multipliers: Size, Determinants, and Use in Macroeconomic Projections. IMF Technical Notes and Manuals 14/04, International Monetary Fund. https://doi.org/10.5089/9781498382458.005

Benczúr, P. - Kátay, G. - Kiss, Á. (2018): Assessing the economic and social impact of tax and benefit reforms: A general-equilibrium microsimulation approach applied to Hungary. Economic Modelling, 75(November): 441-457. https://doi.org/10.1016/j. econmod.2018.06.016

Bernheim, B.D. (1989): A Neoclassical Perspective on Budget deficits. Journal of Economic Perspectives, 3(2): 55-72. https://doi.org/10.1257/jep.3.2.55

Bernhofer, D. - Fernández-Amador, O. - Gächter, M. - Sindermann, F. (2014): Finance, Potential Output and the Business Cycle: Empirical Evidence from Selected Advanced and CESEE Economies. Focus on European Economic Integration, 2014/2: 52-75.

Bi, H. - Shen, W. - Yang, S. (2014): Fiscal limits, external debt, and fiscal policy in developing countries. IMF Working Paper 14/49, International Monetary Fund. https://doi. org/10.5089/9781475521665.001

Blinder, A.S. (1975): Distribution effects and the aggregate consumption function. Journal of Political Economy, 83(3): 447-475. https://doi.org/10.1086/260337

Boone L. - Buti, M. (2019): Right here, right now: The quest for a more balanced policy mix. Vox, CEPR Policy Portal, 18 October. https://voxeu.org/article/right-here-right-now-questmore-balanced-policy-mix. Letöltés ideje: 2020. március 11.

Borio, C. - Disyatat, P. - Juselius, M. (2013): Rethinking potential output: Embedding information about the financial cycle. BIS Working Papers No. 404. https://www.bis.org/ publ/work404.pdf. Letöltés ideje: 2020. március 9.

Bradley, J. - Whelan, K. (1997): The Irish expansionary fiscal contraction: A tale from one small European economy. Economic Modelling, 14(2): 175-201. https://doi.org/10.1016/ S0264-9993(96)01036-X

Bussière, M. - Ferrara, L. - Juillard, M. - Siena, D. (2017): Can Fiscal Budget-Neutral Reforms Stimulate Growth? Model-Based Results. Banque de France, Working Paper No. 625. https://doi.org/10.2139/ssrn.2955120 
Caudal, N. - Georges, N. - Grossmann-Wirth, V. - Guillaume, J. - Lellouch, T. - Sode, A. (2013): A budget for the euro area. Trésor-Economics, No. 120. https://www.tresor. economie.gouv.fr/Articles/7060c4e6-02c3-4e7b-a088-c6627826d8d7/files/febacdd88f92-4a02-9c0b-4c1c7dad5c38. Letöltés ideje: 2020. március 9.

Cœuré, B. (2017): Scars or scratches? Hysteresis in the euro area. Speech at the International Center for Monetary and Banking Studies, Geneva, 19 May. https://www.ecb.europa.eu/ press/key/date/2017/html/ecb.sp170519.en.html. Letöltés ideje: 2020. március 3.

CBO (2013): The Effects of Automatic Stabilizers on the Federal Budget as of 2013. Technical report, Congressional Budget Office. https://www.cbo.gov/publication/43977. Letöltés ideje: 2020. március 3.

Chand, S.K. (1977): Summary Measures of Fiscal Influence. IMF Staff Papers, 24(2): 405-449. https://doi.org/10.2307/3866579

Chand, S.K. (1993): Fiscal Impulse Measures and Their Fiscal Impact. In: Blejer, M.I. - Cheasty, A. (eds): How to Measure Fiscal Deficit. International Monetary Fund, pp. 85-102.

Christiano, L.J. (1984): A reexamination of the theory of automatic stabilizers. Carnegie-Rochester Conference Series on Public Policy, 20(1): 147-206. https://doi. org/10.1016/0167-2231(84)90044-7

Cimadomo, J. (2008): Fiscal Policy in Real Time. ECB Working Paper No 919, European Central Bank. https://www.ecb.europa.eu/pub/pdf/scpwps/ecbwp919.pdf

Coenen, G. - Erceg, C.J. - Freedman, C. - Furceri, D. - Kumhof, M. - Lalonde, R. - Laxton, D. - Lindé, J. - Mourougane, A. - Muir, D. - Mursula, S. - de Resende, C. - Roberts, J. Roeger, W. - Snudden, S. - Trabandt, M. - in't Veld, J. (2012): Effects of Fiscal Stimulus in Structural Models. American Economic Journal: Macroeconomics, 4(1): 22-68. https:// doi.org/10.1257/mac.4.1.22

Cottarelli, C. - Keen, M. (2012): Fiscal Policy and Growth: Overcoming the Constraints. In: Canuto, O. - Leipziger, D.M. (eds): Ascent after Decline: Regrowing Global Economies after the Great Recession, January, pp. 87-133. https://doi.org/10.1596/9780821389423_CH03

DeLong, J.B. - Summers, L. (2012): Fiscal Policy in a Depressed Economy. Brookings Papers on Economic Activity, 43(1): 233-297. https://doi.org/10.1353/eca.2012.0000

Domar, E.D. (1944): The "Burden of the Debt" and the National Income. American Economic Review, 34(4): 798-827.

Draghi, M. (2019): Stabilisation policies in a monetary union. Speech at the Academy of Athens, 1 October. 
Dreyer, J.K. - Schmid, P.A. (2015): Fiscal federalism in monetary unions: hypothetical fiscal transfers within the Euro-zone. International Review of Applied Economics, 29(4): 506-532. http://doi.org/10.1080/02692171.2015.1016407

Duesenberry, J.S. - Eckstein, O. - Fromm, G. (1960): A Simulation of the United States in Recession. Econometrica, 28(October): 749-809. https://doi.org/10.2307/1907563

Eggertsson, G. - Ferrero, A. - Raffo, A. (2014): Can structural reforms help Europe? Journal of Monetary Economics? 61(January): 2-22. https://doi.org/10.1016/j.jmoneco.2013.11.006

Eichengreen, B. (1998): Comment on: Alesina, A. - Perotti, R. - Tavares, J. (1998): The political economy of fiscal adjustments. Brooking Papers on Economic Activity. https:// doi.org/10.2307/2534672

EC (1999): European Commission: The EU economy: 1999 review. No 69. https://ec.europa. eu/economy_finance/publications/pages/publication1732_en.pdf

EC (2000): European Commission: The EU economy: 2000 review. No 71. https://ec.europa. eu/economy_finance/publications/pages/publication1716_en.pdf

EC (2001): European Commission: The EU economy: 2001 review Investing in the future. No 73. https://ec.europa.eu/economy_finance/publications/pages/publication1708_en.pdf

EC (2002): European Commission: The EU economy: 2002 review. No 6. https://ec.europa. eu/economy_finance/publications/pages/publication489_en.pdf

EC (2016): European Commission: The Macroeconomic Imbalance Procedure, Rationale, Process, Application: A Compendium. Institutional Paper 039. https://ec.europa.eu/info/ publications/economy-finance/macroeconomic-imbalance-procedure-rationale-processapplication-compendium_en. Letöltés ideje: 2020. március 12.

EFB (2019): European Fiscal Board: Assessment of the EU fiscal rules with a focus on the six and two-pack legislation. https://ec.europa.eu/info/publications/assessment-eu-fiscalrules-focus-six-and-two-pack-legislation_en. Letöltés ideje: 2020. március 12.

Forni, L. - Momigliano, S. (2005): Cyclical Sensitivity of Fiscal Policies Based on Real-Time Data. Applied Economics Quarterly, 50(3): 299-326.

Giavazzi, F. - Jappelli, T. - Pagano, M. (2000): Searching for non-linear effects of fiscal policy: evidence from industrial and developing countries. European Economic Review, 44(7): 1259-1289. https://doi.org/10.1016/S0014-2921(00)00038-6

Guajardo, J. - Leigh, D. - Pescatori, A. (2011): Expansionary Austerity: New International Evidence. IMF Working Paper No. 158, International Monetary Fund. https://www.imf. org/en/Publications/WP/Issues/2016/12/31/Expansionary-Austerity-New-InternationalEvidence-25021. Letöltés ideje: 2020. március 6. 
Guest, R. - Makin, A.J. (2011): In the Long Run, the Multiplier is Dead: Lessons from a Simulation. Agenda: A Journal of Policy Analysis and Reform, 18(1): 13-21. https://doi. org/10.22459/AG.18.01.2011.02

Hayashi, F. (1987): Tests for Liquidity Constraints: A Critical Survey and Some New Observations. In: Bewley, T. (ed.): Advances in Econometrics Fifth World Congress, 2, Cambridge University Press. https://doi.org/10.1017/CCOL0521345529.005

Heller, P. (2005): Back to basics - Fiscal Space: What It Is and How to Get It. Finance and Development, 42(2). https://www.imf.org/external/pubs/ft/fandd/2005/06/basics.htm. Letöltés ideje: 2020. március 3.

Horváth Ágnes - Jakab M. Zoltán - P. Kiss Gábor - Párkányi Balázs (2006). Tények és talányok: Fiskális kiigazítások makrohatásai Magyarországon. MNB Occasional Papers no. 52, Magyar Nemzeti Bank. https://www.mnb.hu/kiadvanyok/elemzesek-tanulmanyokstatisztikak/mnb-tanulmanyok/mnb-tanulmanyok/op-52-horvath-agnes-jakab-m-zoltanp-kiss-gabor-parkanyi-balazs-tenyek-es-talanyok-fiskalis-kiigazitasok-makrohatasaimagyarorszagon. Letöltés ideje: 2020. március 11.

Huidrom, R. - Kose, M.A. - Lim, J.J. - Ohnsorge, F.L. (2016): Do fiscal multipliers depend on fiscal positions? Policy Research Working Paper Series 7724, The World Bank.

IMF (2015): Fiscal policy and long-term growth. International Monetary Fund. https://www. imf.org/en/Publications/Policy-Papers/Issues/2016/12/31/Fiscal-Policy-and-Long-TermGrowth-PP4964. Letöltés ideje: 2020. március 11.

Jedrzejowicz, T. - P. Kiss, G. - Jirsakova, J. (2009): How to measure tax burden in an internationally comparable way? National Bank of Poland Working Papers No. 56, National Bank of Poland, Economic Institute. https://doi.org/10.2139/ssrn.1752229

Jones, P.M. - Olson, E. - Wohar, M.E. (2015): Asymmetric tax multipliers. Journal of Macroeconomics, 43(March): 38-48. http://doi.org/10.1016/j.jmacro.2014.08.006

Juncker, J.-C. - Tusk, D. - Dijsselbloem, J. - Draghi, M. - Schulz, M. (2015): Az európai gazdasági és monetáris unió megvalósítása. Európai Bizottság. https://ec.europa.eu/ commission/sites/beta-political/files/5-presidents-report_hu.pdf. Letöltés ideje: 2020. március 10.

Lehmann Kristóf - Nagy Olivér - Szalai Zoltán - H. Váradi Balázs (2020): Gazdaságpolitikai ágak közötti koordináció(?) az euroövezetben. Hitelintézeti Szemle, 19(1): 37-64. http:// doi.org/10.25201/HSZ.19.1.3764

MNB (2015): Növekedési Jelentés. Magyar Nemzeti Bank. https://www.mnb.hu/kiadvanyok/ jelentesek/novekedesi-jelentes/2015-12-07-novekedesi-jelentes-2015-december. Letöltés ideje: 2020. március 2. 
Mankiw, N.G. (2000): The Savers-Spenders Theory of Fiscal Policy. NBER working paper No 7571. http://doi.org/10.3386/w7571

Matolcsy György (2015): Egyensúly és növekedés. Magyar Nemzeti Bank, Kairosz Kiadó, Budapest.

Morris, R. - Braz, C.R. - de Castro, F. - Jonk, S. - Kremer, J. - Linehan, S. - Marino, M.R. Schalck, C. - Tkacevs, O. (2009): Explaining government revenue windfalls and shortfalls an analysis for selected EU countries. ECB Working papers No 1114. https://www.ecb. europa.eu/pub/pdf/scpwps/ecbwp1114.pdf. Letöltés ideje: 2020. március 5.

Mourre, G. - Poissonnier, A. - Lausegger, M. (2019): The Semi-Elasticities Underlying the Cyclically-Adjusted Budget Balance: An Update \& Further Analysis. European Commission Discussion paper 098/May.

Musgrave, R.A. (1959): Theory of Public Finances. McGraw-Hill, New York.

Nikolov, P. (2016): Cross-border risk sharing after asymmetric shocks: evidence from the euro area and the United States. Quarterly Report on the Euro Area, 15(2). https://ec.europa. eu/info/sites/info/files/ip030_en_1.pdf. Letöltés ideje: 2020. március 9.

OECD (2016): Economic Policy Reforms 2016: Going for Growth Interim Report. OECD Publishing. https://doi.org/10.1787/growth-2016-en

OECD (2019a): OECD Economic Outlook. OECD Publishing. https://doi.org/10.1787/ b2e897b0-en

OECD (2019b): Economic Policy Reforms 2019: Going for Growth. OECD Publishing. https:// doi.org/10.1787/aec5b059-en

Palotai Dániel (2017): Beértek a 2010-2013 közötti adóreform kedvezö hatásai. MNB szakmai cikk, Magyar Nemzeti Bank. https://www.mnb.hu/letoltes/palotai-daniel-adoreformgyumolcsei-mnb-honlapra.pdf. Letöltés ideje: 2020. március 12.

Perotti, R. (1996): Fiscal Consolidation in Europe: Composition Matters. The American Economic Review, 86(2), Papers and Proceedings of the Hundredth and Eighth Annual Meeting of the American Economic Association San Francisco CA, January 5-7, 1996, pp. 105-110. https://www.jstor.org/stable/2118105?seq=1\#metadata_info_tab_contents. Letöltés ideje: 2020. március 11.

P. Kiss Gábor (2011): Mozgó célpont? Fiskális mutatók jegybanki szemszögből. MNB tanulmányok (MT92), Magyar Nemzeti Bank. https://www.mnb.hu/letoltes/mt92-vegleges. pdf. Letöltés ideje: 2020. március 6.

P. Kiss Gábor (2017): Mi nulla? Mi mennyi? Amit mindig tudni szerettél volna a kiegyensúlyozott költségvetésröl. Köz-Gazdaság, 12(4): 167-199. 
Prammer, D. (2004): Expansionary Fiscal Consolidations? An Appraisal of the Literature on Non-Keynesian Effects of Fiscal Policy and case Study for Austria. OeNB, Monetary Policy \& the Economy Q3/2004. https://econpapers.repec.org/scripts/redir.pf?u=https\%3A\%2F\%2Fwww.oenb.at\%2Fdam\%2Fjcr\%3Ac476adcc-3bb8-42b4-bddc6e00eb41194a\%2Fmop_20043_analyses3_tcm16-21309.pdf; h=repec:onb:oenbmp:y:2004:i:3:b:3. Letöltés ideje: 2020. március 5.

Price, R. - Dang, T.-T. (2011): Adjusting Fiscal Balances for Asset Price Cycles. OECD Economics Department Working Papers No. 868. https://doi.org/10.1787/5kgc42t3zqkl-en

Rachel, L. - Summers, L. (2019): On Secular Stagnation in the Industrialized World. NBER Working Paper No 26198. https://doi.org/10.3386/w26198

Rogoff, K. (2016): Debt Supercycle, Not Secular Stagnation. Progress and Confusion: The State of Macroeconomic Policy. Cambridge: MIT Press, pp. 19-28. https://doi.org/10.7551/ mitpress/10678.003.0003

Romer, C.D. - Romer, D.H. (2010): The Macroeconomic Effects of Tax Changes: Estimates Based on a New Measure of Fiscal Shocks. American Economic Review, 100(3): 763-801. http://doi.org/10.1257/aer.100.3.763

Strulik, H. - Trimborn, T. (2013): The Dark Side of the Fiscal Stimulus. CEGE discussion paper no. 150, January. https://www.econstor.eu/bitstream/10419/70210/1/734961634.pdf. Letöltés ideje: 2020. március 4.

Szoboszlai Mihály - Bögöthy Zoltán - Mosberger Pálma - Berta Dávid (2018): A 2010-2017 közötti adó- és transzferváltozások elemzése mikroszimulációs modellel. MNB tanulmányok (MT135), Magyar Nemzeti Bank. https://www.mnb.hu/letoltes/mnb-tanulma-ny-135vegleges.pdf. Letöltés ideje: 2020. március 12.

Tanzi, V. - Zee, H. (1997): Fiscal Policy and Long-Run Growth. IMF Staff Papers, 44(2): 179209.

Triggs, A. (2018): The economic and political case for coordinating fiscal stimulus. Global Economy \& Development working paper 121, November. https://www.brookings.edu/ wp-content/uploads/2018/11/Triggs_Case-for-coordination-fiscal-stimulus.pdf. Letöltés ideje: 2020. március 12. 